\title{
Electrocatalysts Prepared by Galvanic Replacement
}

\author{
Athanasios Papaderakis ${ }^{1}$, Ioanna Mintsouli ${ }^{1}$, Jenia Georgieva ${ }^{2}$ and Sotiris Sotiropoulos ${ }^{1, *}$ \\ 1 Department of Chemistry, Aristotle University of Thessaloniki, 54124 Thessaloniki, Greece; \\ thpapader@chem.auth.gr (A.P.); ioannamin@yahoo.gr (I.M.) \\ 2 Rostislaw Kaischew Institute of Physical Chemistry, Bulgarian Academy of Sciences, 1113 Sofia, Bulgaria; \\ jenia@ipc.bas.bg \\ * Correspondence: eczss@chem.auth.gr; Tel.: +30-2310-997742
}

Academic Editor: Minhua Shao

Received: 28 December 2016; Accepted: 2 March 2017; Published: 8 March 2017

\begin{abstract}
Galvanic replacement is the spontaneous replacement of surface layers of a metal, $\mathrm{M}$, by a more noble metal, $\mathrm{M}_{\text {noble, }}$, when the former is treated with a solution containing the latter in ionic form, according to the general replacement reaction: $n \mathbf{M}+m \mathbf{M}_{\text {noble }}{ }^{n+} \rightarrow n \mathbf{M}^{m+}+m \mathbf{M}_{\text {noble }}$. The reaction is driven by the difference in the equilibrium potential of the two metal/metal ion redox couples and, to avoid parasitic cathodic processes such as oxygen reduction and (in some cases) hydrogen evolution too, both oxygen levels and the $\mathrm{pH}$ must be optimized. The resulting bimetallic

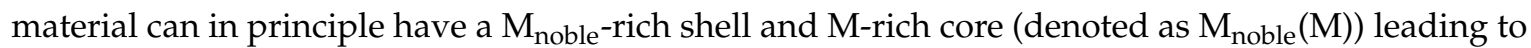
a possible decrease in noble metal loading and the modification of its properties by the underlying metal M. This paper reviews a number of bimetallic or ternary electrocatalytic materials prepared by galvanic replacement for fuel cell, electrolysis and electrosynthesis reactions. These include oxygen reduction, methanol, formic acid and ethanol oxidation, hydrogen evolution and oxidation, oxygen evolution, borohydride oxidation, and halide reduction. Methods for depositing the precursor metal $\mathrm{M}$ on the support material (electrodeposition, electroless deposition, photodeposition) as well as the various options for the support are also reviewed.
\end{abstract}

Keywords: electrocatalysis; fuel cells; electrolysers; metal catalysts; galvanic replacement; transmetalation

\section{Principle of Galvanic Replacement/Deposition}

\subsection{Thermodynamic Considerations}

When a metal, $\mathrm{M}$ (e.g., $\mathrm{Cu}, \mathrm{Fe}, \mathrm{Co}, \mathrm{Ni}, \mathrm{Al}$, etc.), is immersed in a solution containing ions of a more noble metal, $\mathrm{M}_{\text {noble }}{ }^{n+}$ (e.g., $\mathrm{Pt}, \mathrm{Au}, \mathrm{Pd}, \mathrm{Ag}, \mathrm{Ru}, \mathrm{Ir}, \mathrm{Rh}$, Os, etc.-i.e., a metal with a higher standard potential) then, due to the difference in their standard electrochemical potentials, $E_{\text {noble }}^{0}-E^{0}>0$, and provided that the ionic form of $\mathrm{M}$ is stable under the given experimental conditions (of temperatue, $\mathrm{pH}$, complexing agents etc.), the following reaction is thermodynamically favored and can take place spontaneously:

$$
\mathrm{M}_{\text {noble }}{ }^{n+}+n / m \mathrm{M} \rightarrow \mathrm{M}_{\text {noble }}+n / m \mathrm{M}^{m+}
$$

This reaction, which bears similarities with transmetalation reactions between metal complexes [1] and is also known as immersion plating [2] in the plating industry and galvanic replacement [3] in materials chemistry, can be considered to originate from the coupling of the following two half-reactions:

$$
\begin{gathered}
\mathrm{M}_{\text {noble }}{ }^{n+}+n \mathrm{e}^{-} \leftrightarrow \mathrm{M}_{\text {noble }}\left(E^{0}{ }_{\text {noble }}\right) \\
\mathrm{M}^{m+}+m \mathrm{e}^{-} \leftrightarrow \mathrm{M}\left(E^{0}\right)
\end{gathered}
$$


and results in the (complete or partial) dissolution of $\mathrm{M}_{\text {as }} \mathrm{M}^{m+}$ ions and the deposition of $\mathrm{M}_{\text {noble }}$ in metallic form, either on surface sites of remaining $\mathrm{M}$, or on top of already deposited $\mathrm{M}_{\text {noble }}$ atoms, or on nearby substrate locations (provided that the latter is conducting). As examples (relevant to the preparation of electrocatalysts or optically active particles; see below) one may consider the galvanic replacement of metallic $\mathrm{Cu}$ by $\mathrm{Pt}$ or that of metallic Ni by Ag:

$$
\begin{gathered}
2 \mathrm{Cu}+\mathrm{PtCl}_{6}{ }^{2-} \rightarrow \mathrm{Pt}+2 \mathrm{Cu}^{2+}+6 \mathrm{Cl}^{-} \\
2 \mathrm{Ag}^{+}+\mathrm{Ni} \rightarrow 2 \mathrm{Ag}+\mathrm{Ni}^{2+}
\end{gathered}
$$

Alternatively, if for a given metal $\mathrm{M}$ and $\mathrm{pH}$ conditions the oxidized form of $\mathrm{M}$ can only be present as an oxide, $\mathrm{M}_{2} \mathrm{O}_{m}$, or hydroxide, $\mathrm{M}(\mathrm{OH})_{m}$, then the deposition of metallic $\mathrm{M}_{\text {noble }}$ is not coupled with the release of $\mathrm{M}^{m+}$ in the solution but the formation or further growth of oxides/hydroxides of $\mathrm{M}$, either at freshly reduced $\mathrm{M}$ sites or onto already present oxide layers. (Then, a more accurate description of the process should employ the term galvanic deposition-oxide growth instead of galvanic replacement and it is often referred to as spontaneous deposition.) Hence, in the case of oxide formation, galvanic deposition can be described by the following general reaction:

$$
\mathrm{M}_{\text {noble }}{ }^{n+}+n / m \mathrm{M}+n / 2 \mathrm{H}_{2} \mathrm{O} \rightarrow \mathrm{M}_{\text {noble }}+n /(2 m) \mathrm{M}_{2} \mathrm{O}_{m}+n \mathrm{H}^{+}
$$

the driving force now being the $E^{0}$ Mnoble $-E^{0}{ }_{\mathrm{M}_{2} \mathrm{O}_{m}}>0$ difference. As examples (relevant to the preparation of electrocatalysts or the deposition of metal ions on stainless steel containers; see below) one may consider the galvanic deposition of metallic Pt on freshly reduced Ti and Ru as well as that of Ag on Cr-containing materials:

$$
\begin{gathered}
\mathrm{PtCl}_{6}{ }^{2-}+\mathrm{Ti}+2 \mathrm{H}_{2} \mathrm{O} \rightarrow \mathrm{Pt}+\mathrm{TiO}_{2}+6 \mathrm{Cl}^{-}+4 \mathrm{H}^{+} \\
\mathrm{PtCl}_{6}{ }^{2-}+4 \mathrm{Ru}+4 \mathrm{H}_{2} \mathrm{O} \rightarrow \mathrm{Pt}+4 \mathrm{RuOH}+6 \mathrm{Cl}^{-}+4 \mathrm{H}^{+} \\
3 \mathrm{Ag}^{+}+\mathrm{Cr}+3 \mathrm{H}_{2} \mathrm{O} \rightarrow 3 \mathrm{Ag}+\mathrm{Cr}(\mathrm{OH})_{3}+3 \mathrm{H}^{+}
\end{gathered}
$$

As mentioned above, an indication of the thermodynamic driving force for galvanic replacement/deposition is given by the difference in the standard potentials of the half-cell reactions involving the two metals; a series of such half-cell reactions often encountered in galvanic replacement/deposition and their standard potentials (taken from [4]) is given in Table 1. The left-hand side of the table contains metals that are usually deposited during the process (the forward of the half-cell reaction) whereas the right-hand side contains those that are usually dissolved/oxidized (the reverse of the half-cell reaction). The larger the difference between the potential of a left-hand side reaction and that of a right-hand side one, the more favorable their coupling into a galvanic replacement/deposition process. For example, from the reactions presented in Table 1 the two most favorable reactions would be the deposition of $\mathrm{Au}$ on freshly reduced $\mathrm{Cr}$ or $\mathrm{Al}$ with the simultaneous oxidation of the latter into $\mathrm{Cr}(\mathrm{OH})_{3}$ or $\mathrm{Al}(\mathrm{OH})_{3}$, since the combination of the relevant half-cell reactions have a potential difference of $+1.002-(-1.126)=+2.128 \mathrm{~V}$ vs. SHE (Standard Hydrogen Electrode) and $+1.002-(-2.300)=+3.302 \mathrm{~V}$ vs. SHE respectively. It is obvious that before embarking on thermodynamic calculations that provide an estimate of the tendency of a galvanic replacement/deposition reaction to occur one should take into consideration the following: (i) the Pourbaix diagram of the metal $\mathrm{M}$ that is tested for replacement, to identify the forms in which it may exist under the given $\mathrm{pH}$ and aeration conditions and the corresponding standard potentials (for example, in aerated neutral solutions $\mathrm{Cr}$ should be present as $\mathrm{Cr}_{2} \mathrm{O}_{3}$ [5] rendering galvanic deposition of Ag simply via reaction (9) impossible to take place on defect-free chrome surfaces); (ii) standard potentials should be corrected to their equilibrium values, taking into account the exact metal ions concentration [6]; and (iii) the possibility of metal complexation, depending on the presence of ligands, which should be taken into account when considering the half reactions since this may not only affect 
the corresponding potential but also the valence of the metals and the stoichiometry of the reaction (as pointed out by Brankovic and co-workers [6,7], who provided evidence that, in the absence of any other than $\mathrm{Cl}^{-}$ligands, reaction (4) above may be replaced by one involving the replacement of four $\mathrm{Cu}$ atoms by one $\mathrm{Pt}$ with the formation of the stable $\mathrm{Cu}(\mathrm{I})$ complex of $\mathrm{CuCl}_{2}{ }^{-}$). Indeed, one has to stress that some of the reduction potentials tabulated in the right-hand columns of Table 1 may decrease significantly in the presence of strongly complexing ligands (see, for example, the case of the $\mathrm{Cu}(\mathrm{I}) / \mathrm{Cu}$ couple in the presence of $\mathrm{Cl}^{-}$).

Table 1. Standard potentials of half-cell reactions involving some metals participating in galvanic replacement/deposition reactions. SHE, Standard Hydrogen Electrode.

\begin{tabular}{|c|c|c|c|}
\hline Reaction & $E^{0}$ vs. SHE/V & Reaction & $E^{0}$ vs. SHE/V \\
\hline $\begin{aligned} \mathrm{RuCl}_{3}+3 \mathrm{e}^{-} & \leftrightarrow \mathrm{Ru}+3 \mathrm{Cl}^{-} \\
\mathrm{PdCl}_{4}{ }^{2-}+2 \mathrm{e}^{-} & \leftrightarrow \mathrm{Pd}+4 \mathrm{Cl}^{-} \\
\mathrm{PtCl}_{6}{ }^{2-}+4 \mathrm{e}^{-} & \leftrightarrow \mathrm{Pt}+6 \mathrm{Cl}^{-} \\
\mathrm{PtCl}_{4}{ }^{2-}+2 \mathrm{e}^{-} & \leftrightarrow \mathrm{Pt}+4 \mathrm{Cl}^{-} \\
\mathrm{Ag}^{+}+\mathrm{e}^{-} & \leftrightarrow \mathrm{Ag} \\
\mathrm{IrCl}_{6}{ }^{2-}+4 \mathrm{e}^{-} & \leftrightarrow \mathrm{Ir}+6 \mathrm{Cl}^{-} \\
\mathrm{AuCl}_{4}+ & +3 \mathrm{e}^{-} \leftrightarrow \mathrm{Au}+4 \mathrm{Cl}^{-}\end{aligned}$ & $\begin{array}{l}+0.386 \\
+0.620 \\
+0.744 \\
+0.730 \\
+0.799 \\
+0.860 \\
+1.002\end{array}$ & $\begin{aligned} & \mathrm{Cu}^{+}+\mathrm{e}^{-} \leftrightarrow \mathrm{Cu} \\
& \mathrm{Cu}^{2+}+2 \mathrm{e}^{-} \leftrightarrow \mathrm{Cu} \\
& \mathrm{CuCl}^{+} \mathrm{e}^{-} \leftrightarrow \mathrm{Cu}+\mathrm{Cl}^{-} \\
& \mathrm{Fe}^{3+}+3 \mathrm{e}^{-} \leftrightarrow \mathrm{Fe} \\
& \mathrm{RuOH}+\mathrm{e}^{-}+\mathrm{H}^{+} \leftrightarrow \mathrm{Ru}+\mathrm{H}_{2} \mathrm{O} \\
& \mathrm{Pb}^{2+}+2 \mathrm{e}^{-} \leftrightarrow \mathrm{Pb} \\
& \mathrm{Sn}^{2+}+2 \mathrm{e}^{-} \leftrightarrow \mathrm{Sn} \\
& \mathrm{Ni}^{2+}+2 \mathrm{e}^{-} \leftrightarrow \mathrm{Ni} \\
& \mathrm{Co}^{2+}+2 \mathrm{e}^{-} \leftrightarrow \mathrm{Co} \\
& \mathrm{Ni}(\mathrm{OH})_{3}+3 \mathrm{e}^{-} \leftrightarrow \mathrm{Ni}+3 \mathrm{OH}^{-} \\
& \mathrm{Fe}^{2+}+2 \mathrm{e}^{-} \leftrightarrow \mathrm{Fe} \\
& \mathrm{Zn}^{2+}+2 \mathrm{e}^{-} \leftrightarrow \mathrm{Zn} \\
& \mathrm{TiO}_{2}+4 \mathrm{e}^{-}+4 \mathrm{H}^{+} \leftrightarrow \mathrm{Ti}+2 \mathrm{H}_{2} \mathrm{O} \\
& \mathrm{Cr}(\mathrm{OH})_{3}+3 \mathrm{e}^{-} \leftrightarrow \mathrm{Cr}+3 \mathrm{OH}^{-} \\
& \mathrm{Al}(\mathrm{OH})_{3}+3 \mathrm{e}^{-} \leftrightarrow \mathrm{Al}+3 \mathrm{OH}^{-}\end{aligned}$ & $\begin{array}{l}+0.520 \\
+0.340 \\
+0.121 \\
-0.040 \\
-0.050 \\
-0.126 \\
-0.136 \\
-0.257 \\
-0.277 \\
-0.320 \\
-0.440 \\
-0.763 \\
-1.095 \\
-1.126 \\
-2.300\end{array}$ \\
\hline
\end{tabular}

\subsection{Kinetic Considerations}

In estimating the rate of galvanic replacement/deposition in practice (which in turn may determine the morphology, structure and properties of the deposits) one has to look also into the kinetics of the process. There are rather few papers studying the time evolution of galvanic replacement processes. Most of them deal with the kinetics of the galvanic replacement of an underpotentially deposited (upd) monolayer of $\mathrm{Cu}$ or Pb by more noble metals. The first paper was by Dimitrov and co-workers [8] followed by the works of Brankovic and co-workers $[9,10]$. These researchers have developed models whereby the coverage $\theta$ of the upd layer that is being replaced is correlated to time and, by the correlation of $\theta$ with the substrate potential via an adsorption isotherm, open circuit potential (ocp) vs. time expressions were obtained and validated by monitoring the substrate ocp as the galvanic replacement proceeds. They have treated cases of both mass transfer and kinetic control. More recent publications have taken into account the effects of solution composition [11] as well as those of surface heterogeneity and sequential multilayer formation [12].

When it comes to galvanic replacement of metal multilayers from nanoparticles or nanoparticulate films, there is a single paper that employed chronopotentiometry to monitor $\mathrm{Pt}$ deposition on $\mathrm{Cu}$ layers from acidic solutions; that process was found to be Pt-species diffusion limited, since both the kinetics of $\mathrm{Pt}$ deposition and of $\mathrm{Cu}$ dissolution in acid were very fast [13]. Given the fact that galvanic replacement can be essentially viewed as a corrosion reaction whereby a metal substrate is oxidized/dissolved (anodic reaction) while a more noble metal is reduced/deposited (cathodic reaction), we hereby propose to treat galvanic replacement kinetics by analogy to corrosion kinetics, according to a phenomenological approach. Corrosion kinetics are characterized by a corrosion current density, $j_{\text {corr }}$, which in turn can be related to a metal dissolution rate via Faraday's law. By analogy to $j_{\text {corr }}$ one can define (under no mass transfer limitations) for the combination of reactions similar to (2) and (3) above a galvanic current density, $j_{\text {galv }}$, according to [14] as: 


$$
j_{\text {galv }}=\left(j_{0, \mathrm{M}_{\text {noble }}}\right)^{\beta_{1}}\left(j_{0, \mathrm{M}}\right)^{\beta_{2}} \exp \left[\frac{2.3\left(E_{e}^{\mathrm{M}_{\text {noble }}}-E_{e}^{\mathrm{M}}\right)}{\beta_{\mathrm{M}_{\text {noble }}}+\beta_{\mathrm{M}}}\right]
$$

where $j_{0, \mathrm{M}_{\text {noble }}}$ and $j_{0, \mathrm{M}}$ are the exchange current densities of reactions similar to (2) and (3) respectively,

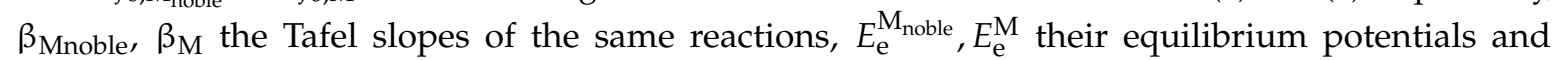
$\beta_{1}=\beta_{\text {Mnoble }} /\left(\beta_{\text {Mnoble }}+\beta_{M}\right), \beta_{2}=\beta_{M} /\left(\beta_{\text {Mnoble }}+\beta_{M}\right)$. The equilibrium potentials can be estimated based on their standard values and the experimental conditions (temperature, metal ion concentration, ligand concentration and $\mathrm{pH}$ if relevant) while the exchange current densities and Tafel slopes can be determined experimentally. Equation (10) leads to the important conclusion that it is not only the thermodynamics but also the kinetics of a galvanic replacement process that is determined by the equilibrium potential difference of the two metals (in cases where both half-cell reactions are under pure kinetic control). (Note, however, that, since the concentrations of the metal ions involved change as the process proceeds (that of the more noble metal decreases while that of the other metal may increase), so do the equilibrium potentials (according to the Nernst equation) and as a result both the potential difference in Equation (10) and the galvanic replacement rate decrease in time.)

In the case of relatively fast $\mathrm{M}$ dissolution rates and if $\mathrm{M}_{\text {noble }}{ }^{n+}$ deposition is under mass transfer control, then the galvanic current density/rate will be determined by $\mathrm{M}_{\text {noble }}{ }^{n+}$ mass transfer. For example, in the case of stationary solutions, the mass transfer controlled galvanic replacement current density can also be written (according to the Cottrell equation) as:

$$
j_{\text {galv }}=n F k_{m} C_{\mathrm{M}_{\text {noble }}^{n+}}=\frac{n F D^{1 / 2} C_{\mathrm{M}_{\text {noble }}^{n+}}}{\left(\pi t^{1 / 2}\right)}
$$

while the decrease in $\mathrm{M}_{\text {noble }}{ }^{n+}$ concentration should be given by:

$$
-\frac{d C_{\mathrm{M}_{\text {noble }}^{n+}}}{d t}=\frac{D^{1 / 2} C_{\mathrm{M}_{\text {noble }}^{n+}}}{\left(\pi t^{1 / 2}\right)} \frac{A}{V}
$$

where $k_{m}$ is the mass transfer coefficient, $A$ is the substrate surface area and $V$ the solution volume. It should be stressed that the above analysis strictly holds for large substrates of pure metal $\mathrm{M}$ of a known area $A$ in contact with $\mathrm{M}_{\text {noble }}{ }^{n+}$. It could therefore only serve as a qualitative predictor of galvanic replacement/deposition kinetics in cases that the process occurs through defects in oxide passivation layers or that the partial current density corresponding to $\mathrm{M}_{\text {noble }}{ }^{n+}$ reduction/deposition is sustained by the passivation partial current density of $\mathrm{M}$ dissolution through a homogeneous protective oxide via a high-field mechanism (see, for example, [15]). Nevertheless, in the latter case, if the rate is controlled by diffusion of $\mathrm{M}_{\text {noble }}{ }^{n+}$ to the entire passivated surface, then Equations (11) and (12) may still be applicable.

\section{History and Applications of Galvanic Replacement/Deposition}

\subsection{Metal Finishing, the Electronics Industry, and Metallurgical Applications}

Galvanic replacement has been widely used in the printed circuit board (PCB) technology and the metal finishing industry in general [16-19], under the name of immersion plating. For example, tin/lead immersion coatings on $\mathrm{Cu}$ (from baths containing appropriate complexing agents) [20] and gold or silver immersion coatings on $\mathrm{Cu}$ (sometimes coupled with $\mathrm{Ni}$ electroless plating) [21-23] are common practice in PCB fabrication. Also, $\mathrm{Zn}$ and $\mathrm{Cu}$ immersion coatings on aluminum have been used for anticorrosion, primer plating, or decorative purposes [24-26]. Finally, $\mathrm{Cu}$ immersion plating has been used for corrosion protection of stainless steel substrates [27].

In a less well-known application, galvanic deposition has been used in hydrometallurgy as a means of retrieving metals from their solutions onto appropriate metallic substrates [28] (in that case it 
is often classified as cementation). For example, $\mathrm{Cu}$ was being recovered from mining effluents using iron substrates as collectors [29]. Similarly, it was recently shown that the decrease in biocide Ag ion concentration observed in potable water stored in stainless steel tanks used in space missions was due to Ag galvanic deposition on stainless steel, with simultaneous growth of oxides of the latter [30].

\subsection{Ultrathin Film Applications}

Galvanic replacement has also been applied to the formation of ultrathin (even atomically thin) epitaxial metal layers over a metal substrate, with the technique known as surface limited redox replacent (SLRR) (see the excellent reviews of [6,31]); such films have unique electronic, optical and catalytic properties that make them indispensable components of advanced electronic and optoelectronic devices. This process belongs to the larger family of surface-limited reactions (SLR) and more specifically to those that the first step involves the formation of a monolayer of a metal (most often) or hydrogen, sulphur or iodine atoms by means of their reductive or oxidative deposition at potentials more positive or negative respectively than that required for bulk deposition; these monolayers are known as uderpotential deposits (upd; see, for example, [32]). Historically, the first application of a SLR based on upd was for the preparation of epitaxial layers of semiconductor compounds (e.g., $\mathrm{CdTe}, \mathrm{GaAs}$ ) and was due to Stickney and co-workers [33-36], who established the technique as electrochemical atomic layer epitaxy (ECALE). However, the first application of SLRR to prepare a metal monolayer on a metal substrate by galvanic replacement of a pre-deposited metal upd was due to Brankovic et al. [37], who deposited Pt submonolayers, Pd monolayers and Ag bilayers on a $\mathrm{Au}(111)$ substrate by the galvanic replacement of a $\mathrm{Cu}$ upd monolayer (the difference in atomic layer coverage resulted from the use of $\mathrm{Pt}(\mathrm{IV}), \mathrm{Pd}(\mathrm{II})$, and $\mathrm{Ag}(\mathrm{I})$ solutions and the stoichiometry of the corresponding exchange reactions that involved $\mathrm{Cu}$ oxidation to $\mathrm{Cu}(\mathrm{II})$ ). Subsequently, Weaver and co-workers [38] used successive applications of the two elementary steps (upd deposition and redox replacement) to create multilayer Pt coatings consisting of epitaxially deposited monolayers. Following these early works, Dimitrov and co-workers [39-46] and Stickney and co-workers [47-53] fully explored the technique for the preparation of a number of noble metal layers with atomic layer epitaxy. They further advanced practical aspects of the method that include automation of the process using a flow cell [51], a single-cell approach with careful control of upd deposition and ion concentrations [42], the use of adsorbed $\mathrm{H}$ as a sacrificial layer [44,53], the electroless deposition of the sacrificial upd layer by short circuiting the substrate with an appropriate counter electrode $[45,46]$ and even some electrocatalytic applications [43,52].

\subsection{Nanoparticle and Catalytic Layer Applications}

Of the most recent applications of galvanic replacement in materials chemistry has been the preparation of bimetallic (often core-shell) or/and hollow nanoparticles, having useful optical, magnetic and/or catalytic properties, as recently reviewed in [54]. One of the first relevant works involved the preparation of $\mathrm{Au}, \mathrm{Pt}$, and $\mathrm{Pd}$ nanoparticles by the replacement of $\mathrm{Cu}$ or $\mathrm{Ag}$ precursors encapsulated in organic dendrimers [55]; the thus-prepared Pt and Pd nanoparticles showed enhanced oxygen reduction electrochemical activity. Examples of other early papers that followed include the preparation of $\mathrm{Pt}-\mathrm{Co}$ nanoparticles and the exploration of their magnetic properties [56], the preparation of $\mathrm{Au}-\mathrm{Ag}, \mathrm{Pd}-\mathrm{Ag}, \mathrm{Au}-\mathrm{Pd}$ and $\mathrm{Au}-\mathrm{Cu}$ bimetallic particles with modified plasmonic behavior [57] and the preparation of hollow $\mathrm{Pt}, \mathrm{Pd}$, and Au nanostructures using Ag nanoparticle or nanotube templates [58]. Au nanocages prepared by galvanic replacement have also found applications in medicine for targeted cancer therapy and imaging, due to their localized surface plasmon resonance properties that allow heat conversion of Near-infrared (NIR) radiation (see, for example, $[59,60]$ ).

Following the elegant work of [55], there have been many reports on the preparation of bimetallic and/or hollow electrocatalysts and reviews of such catalysts used in fuel cells or/and other energy applications are given in [61,62] and [63] respectively. Among the most systematic series of works in the preparation, characterization and testing of electrocatalysts prepared by galvanic 
replacement/deposition one has to mention that of Adzic and co-workers (see, for example, [64-66]), Kokkinidis and Sotiropoulos and co-workers (see, for example, $[67,68]$ ), Podlovchenko and co-workers (see, for example, [69,70]) and Musiani and co-workers (see, for example, [71,72]).

In more detail, Kokkinidis and co-workers prepared Pt-modified Ti electrodes on freshly polished Ti substrates by galvanic deposition and used them as hydrogen evolution and oxygen reduction cathodes [73,74]; shortly afterwards they have prepared $\mathrm{Pt}-\mathrm{Cu}$ and $\mathrm{Pt}-\mathrm{Pb}$ modified electrodes for oxygen reduction, by partial galvanic replacement of $\mathrm{Cu}$ and Pd bulk metal adlayers $[75,76]$. During the same time period, Adzic and co-workers prepared Pt-modified Ru electrodes on reduced $\mathrm{Ru}(0001)$ surfaces or Ru nanoparticles by galvanic deposition and used them as CO-tolerant anodes [77,78]; they were also the first to demonstrate the possibility of forming $\mathrm{Pt}, \mathrm{Pd}$, and $\mathrm{Ag}$ sub-monolayers or monolayers on $\mathrm{Au}(001)$ by the complete galvanic replacement of a $\mathrm{Cu}$ under-potentially deposited monolayer [37]. Following these pioneering papers in the area, Adzic and co-workers embarked on a very systematic study of various poly-metallic systems of noble metal sub-monolayer/monolayer shells (mostly Pt and Pd) over a noble metal core (mostly Pd or $\mathrm{Au}$ ), always using the $\mathrm{Cu}$ upd replacement method; in some cases they also produced mixed noble metal shells and mixed noble/less-noble metal cores (see, for example, [64-66,79-97]). Most of their work focused on the use of these catalysts as efficient oxygen reduction cathodes, although they also studied them as alcohol and $\mathrm{CO}$ anodes as well. They were the first to scale up this preparation route to practical carbon-supported catalysts [90], soon followed by other work $[53,98,99]$. On the other hand, Sotiropoulos and co-workers continued the partial galvanic replacement of metal poly-layers $(\mathrm{Cu}, \mathrm{Pb}, \mathrm{Fe}, \mathrm{Co}, \mathrm{Ni})$ by more noble metals (mainly $\mathrm{Pt}, \mathrm{Au}, \mathrm{Ru}, \mathrm{Ir}$ ) and used the resulting electrodes in a number of fuel cell and electrolysis relevant reactions (oxygen reduction, methanol oxidation, borohydride oxidation, hydrogen and oxygen evolution) $[67,68,100-113]$. In a similar research path, Podlovchenko and co-workers, prepared thin deposits of noble metals (mainly $\mathrm{Pt}, \mathrm{Pd}$, and $\mathrm{Au}$ ) on a number of less noble metals $(\mathrm{Cu}, \mathrm{Mo}, \mathrm{Bi}$ ) by their partial galvanic replacement while also adopting the $\mathrm{Cu}$ upd technique too $[69,70,114-128]$; the resulting electrodes were tested mainly for methanol and formic acid oxidation. Musiani and co-workers prepared $\mathrm{Ru}, \mathrm{Ir}, \mathrm{Rh}$, and $\mathrm{Ag}$ deposits on a number of supports made of $\mathrm{Cu}$, $\mathrm{Ni}$, or Fe alloys by the partial galvanic replacement of surface layers of the latter from the former [71,72,129-138]; they used the modified electrodes under alkaline conditions mainly in cathodic reactions (hydrogen evolution, nitrate reduction, organics reduction) but also in some anodic reactions too (alcohol oxidations) and in gas-phase catalysis. Similar work on hydrogen evolution on Ru- or Ir-modified Ni has been reported by Trasatti and co-workers [139,140]. Finally, there have been a few papers where galvanic replacement of metal ions from their oxides has been used to prepare mixed oxides or oxide overlayers over other oxides; such systems involved oxides and ions of elements with multiple oxidation states, such as Mn, Fe, Co, and Sn [141,142].

\section{Characteristics of the Two Galvanic Replacement Approaches for Electrocatalyst Preparation}

From the historical background given above it follows that the approaches for galvanic replacement are based in one of the following paths: either the complete replacement of a $\mathrm{Cu}, \mathrm{Pb}$, or $\mathrm{H}$ upd monolayer by the noble metal catalyst $\mathrm{M}_{\text {noble }}$ (mainly due to the groups of Adzic, Brankovic, Dimitrov, and Stickney) or the partial replacement of surface layers of a metal $\mathrm{M}$ by layers of the more noble metal catalyst $\mathrm{M}_{\text {noble }}$ (adopted in most other works).

A schematic representation of the first approach is depicted in Figure 1A, where, for the sake of simplicity, the noble metal species in solution is assumed to carry a net charge of +2 so that one of its atoms replaces one atom of $\mathrm{Cu}$ upd.

There are two main advantages of this method. First, it leads to minimal amounts of the desired noble metal catalyst as the latter is only present as a thin overlayer. Ideally this can be a monolayer or sub-monolayer, depending on reaction stoichiometry, if a direct exchange growth mechanism is operative, whereby each noble metal atom strongly interacts with upd atoms and deposits only on top of them [31]. On the contrary, if a local cell growth mechanism prevails (i.e., noble metal atoms are 
deposited on each other while the upd metal dissolves from a nearby location) then a slightly thicker, incomplete layer is expected [31]. In both cases, however, the relatively thin noble metal layer results in very high currents per $\mathrm{mg}$ of catalyst, thus decreasing significantly the cost. Second, the thin $\mathrm{M}_{\text {noble }}$ overlayer is prone to significant modifications of its electronic properties by the underlying metals of the core, either via geometric or ligand effects $[143,144]$. For sub-monolayers and nanoclusters, finite size effects have also to be taken into account due to the different strain exerted by the substrate to small particles from that to continuous films; in this way the electronic properties and catalytic activity modification can also be correlated to particle size [145-147]. Adzic and co-workers have systematically explored these effects and reported some of the highest Pt utilization values for oxygen reduction and alcohol oxidation (see, for example, [64-66,94,95]) while also finely tuning the shell properties by using multi-metallic cores that contain apart from a second noble metal $\mathrm{M}_{\text {noble }}^{\prime}$ other noble or less noble metals $\mathrm{M}$ (see, for example, $[87,93,96])$. Among potential drawbacks of the technique is the need for electrodeposition of the sacrificial $\mathrm{Cu}, \mathrm{Pb}$, or $\mathrm{H}$ layer on a second noble metal $\mathrm{M}_{\text {noble support (upd }}^{\prime}$ formation requires potentiostatic control or an appropriate galvanic cell $[45,46]$, as well as a noble metal substrate), which complicates the preparation setup and increases the cost of materials. (Note that the recently proposed chemical formation of adsorbed sacrificial $\mathrm{H}$ on Pd [53] eliminates the need for an electrochemical cell but restricts the use of the method to Pd substrates.) Also, the presence of a single monolayer of the most active catalyst components raises issues of stability (although no long-term performance deterioration has been reported [80,93]).
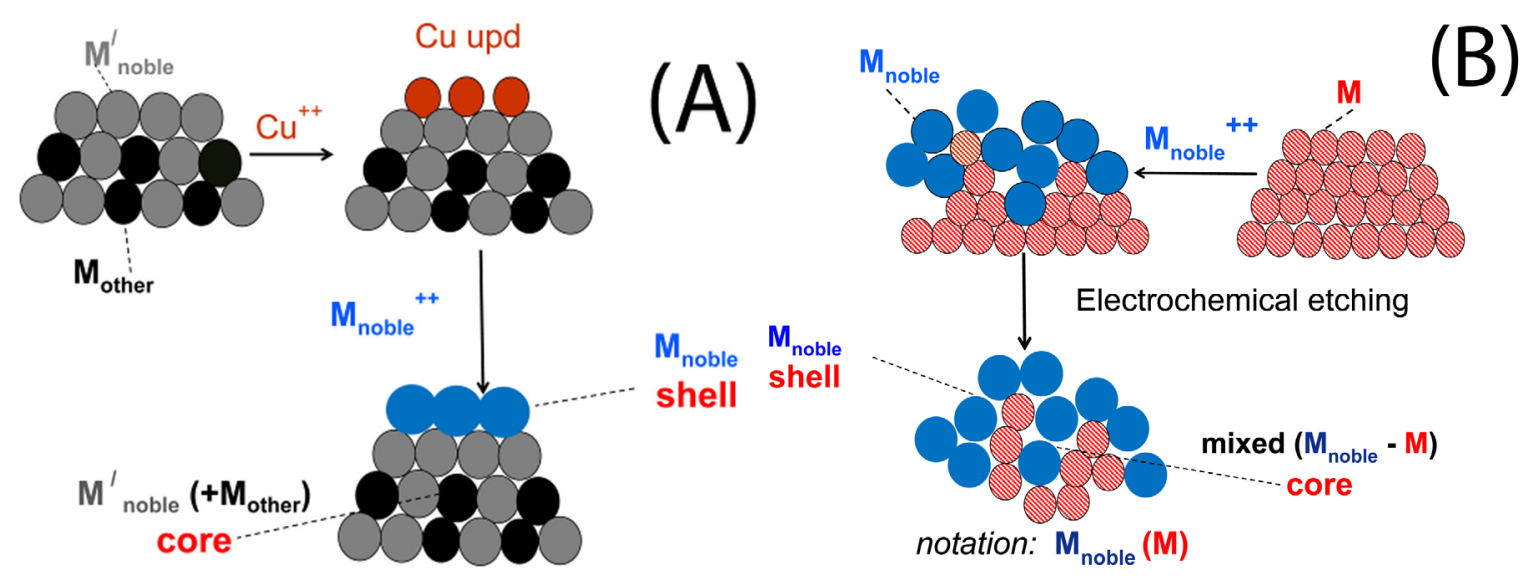

Figure 1. Schematic representation of the mechanism of the two main approaches for galvanic replacement at an atomic level: (A) Replacement of $\mathrm{Cu}$ upd monolayer, formed on a noble metal $\mathrm{M}^{\prime}$ noble substrate (that may also contain another metal, $\mathrm{M}_{\mathrm{other}}$ ), by the noble metal of interest, $\mathrm{M}_{\text {noble; }}$; (B) replacement of atoms of a reactive metal substrate, $M$, by the noble metal of interest, $M_{\text {noble, }}$, followed by electrochemical etching/anodization.

A schematic representation of the second approach is depicted in Figure 1B, where, again, for the sake of simplicity, the noble metal $\left(\mathrm{M}_{\text {noble }}\right)$ and less noble metal $(\mathrm{M})$ replacement reaction is assumed to have a 1:1 stoichiometry ratio. In this case, however, a thicker shell of $\mathrm{M}_{\text {noble }}$ is formed and the latter also enters the core of the catalyst, resulting in a $\mathrm{M}_{\text {noble }}-\mathrm{M}$ mixed core (evidence of that is presented in [102] and discussed in the next section). If the galvanic replacement step does not proceed to the completion of a full noble metal shell (as is the case of either slow or uneven processes) and there is no further catalyst treatment, then the surface of the material contains both $\mathrm{M}_{\text {noble }}$ and $\mathrm{M}$ sites and can usually only be employed as a cathode under alkaline conditions (otherwise $\mathrm{M}$ will be leached); this is the case of catalytic layers produced on bulk $\mathrm{Cu}, \mathrm{Ni}$, and $\mathrm{Fe}$ alloy substrates and used as cathodes in aqueous media by Musiani and co-workers [129,132,134,137,138] and Trasatti and co-workers $[139,140]$. However, if the starting material is made of nanoparticles of $\mathrm{M}$ then, choosing the appropriate preparation conditions (e.g., concentration of $\mathrm{M}_{\text {noble }}$ ions, complexing agents, time 
of reaction) or/and catalyst post-treatment (e.g., acid pepsis) a variety of interesting nanoparticle structures can be obtained (including hollow $\mathrm{M}_{\text {noble }}$ or $\mathrm{M}_{\text {noble }}-\mathrm{M}$ nanoparticles), as reviewed in [54]. Finally, if the initially formed $\mathrm{M}_{\text {noble }} \mathrm{M}$ layers or particles are prepared on an electrode substrate or formed into an electrode and are exposed to anodic potentials then, by selective anodic dissolution of uncovered areas, an $\mathrm{M}_{\text {noble }}$ shell- $\left(\mathrm{M}_{\text {noble }} \mathrm{M}^{\mathrm{M}}\right)$ core structure may be formed (see lower part of Figure 1B) as presented in [100-110]; these catalytic electrodes can then work as anodes and/or in acid solutions due to the protective $M_{\text {noble }}$ shell and shall be denoted as $M_{\text {noble }}(M)$ hereafter. Note that, although this post-treatment is essentially the same as the electrochemical de-alloying introduced and established by Strasser and co-workers (see, for example, the recent review of [148]), the core of the particle in the case of galvanic replacement is formed via a room/moderate temperature process (and results in partial $\mathrm{M}_{\text {noble }}-\mathrm{M}$ alloying [100-110]), whereas that of the latter method is prepared by elevated temperature annealing or hydrothermal routes (and results in a well-defined core alloy). Advantages of the second approach for galvanic replacement (when coupled with the formation of a noble metal shell) over the one based on a upd layer include the expected higher stability of the thicker noble metal skin, the fact that electrodeposition of the upd monolayer on a second noble metal is not needed and the use of a less expensive and more reactive metal core (e.g., $\mathrm{Cu}, \mathrm{Fe}, \mathrm{Co}, \mathrm{Ni}, \mathrm{Pb}$ ); that core, consisting of atoms much smaller and much less electronegative than the noble metal, is also expected to exert a stronger effect on the properties of the latter $[143,144]$. Drawbacks come from the increased thickness of the noble metal skin, which leads to a cost increase and an attenuation of the core electronic and geometric effects on the outmost noble metal layers.

\section{Types of Support, Methods of Less Noble Metal Preparation/Deposition and Catalyst Characteristics}

Strictly speaking, all electrocatalysts have to be supported on an electronic conductor or semiconductor support that is either in the form of particles and/or a solid block that acts as a current collector. However, we shall distinguish here between electrocatalysts prepared by galvanic replacement in those that the support material is present during their preparation (supported catalysts) and those that are initially formed in the absence of a support material and subsequently mixed with or applied onto the support.

In basic research studies, where the focus has been the feasibility and the mechanism of the method as well as the morphology and the interactions between the multi-metallic system components, well-characterized smooth electrode substrates (such as Au and Ru monocrystals [37,77] Ti and Au discs [73-76] and glassy carbon, GC $[67,100-106,109,113])$ have been used. Also, in those cases, the preferred preparation method of the sacrificial upd monolayer or of the precursor less noble metal $\mathrm{M}$ multi-layers has been that of electrodeposition (offering accurate control of the coverage and/or thickness and morphology of the deposits of M). Figure 2 presents a schematic diagram of the expected structure of bimetallic $\mathrm{Pt}(\mathrm{M})$ particles prepared by the partial galvanic replacement of surface layers of $\mathrm{M}$ from their thin bulk electrodeposits on a smooth GC electrode.

Two situations can be envisased: the first is when the process is fast and a protective thin $\mathrm{Pt}$ overlayer is quickly formed, leaving a continuous $\mathrm{M}$ underlayer; the second is when the process is slow and $\mathrm{M}$ has time to completely dissolve from certain sites, leaving $\mathrm{Pt}(\mathrm{M})$ particles on the GC surface, with a relatively thick Pt shell and Pt penetration into the particle core. One of the parameters that may affect the rate of the process and hence the morphology of the deposit is, according to the reasoning of Section 1 above, the $E_{\mathrm{e}}^{\mathrm{M}_{\text {noble }}}-E_{\mathrm{e}}^{\mathrm{M}}$ difference (in this example the $E_{\mathrm{e}}^{\mathrm{Pt}}-E_{\mathrm{e}}^{\mathrm{M}}$ difference). The larger this difference, the more likely is the morphology of the deposit to be that depicted at the top of Figure 2; the smaller, the more likely it is to look like that at the bottom of the same figure. 


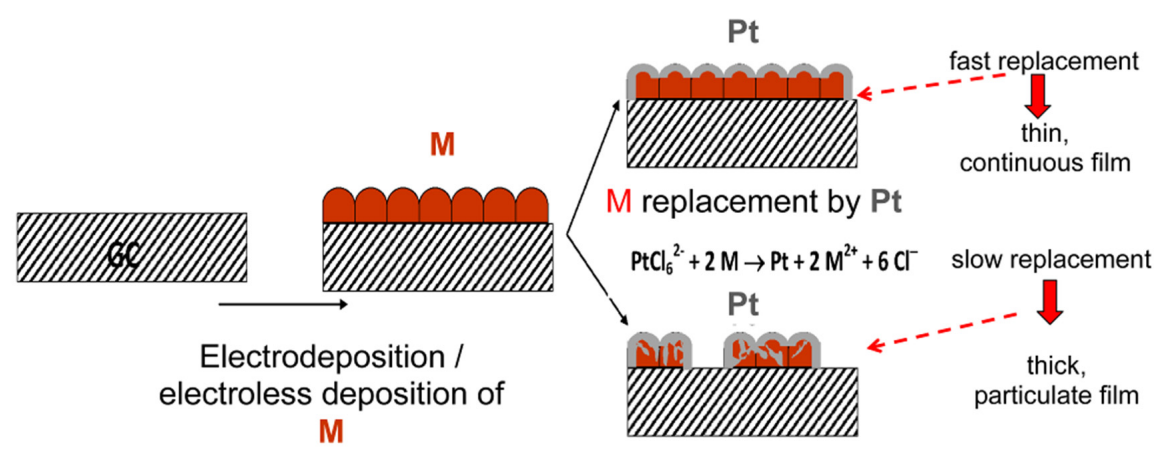

Figure 2. Schematic representation of the morphology of "platinized" M deposits, $\mathrm{Pt}(\mathrm{M})$, prepared by the galvanic replacement of continuous M layers deposited on smooth glassy carbon, GC, substrate: Continuous $\mathrm{Pt}(\mathrm{M})$ layer for fast replacement rates (top part); Particulate $\mathrm{Pt}(\mathrm{M})$ deposit for slow replacement rates (bottom part).

Figure 3 shows such $\mathrm{Pt}(\mathrm{Cu})$ and $\mathrm{Pt}(\mathrm{Co})$ bimetallic layers formed by the galvanic replacement of electrodeposited $\mathrm{Cu}$ or Co layers on GC by $\mathrm{Pt}[101,103]$. It can be seen that, in accordance with $E_{\mathrm{e}}{ }^{\text {Co }}$ being lower than $E_{\mathrm{e}}{ }^{\mathrm{Cu}}$ (see Table 1 above) and with the previous argument, the $\mathrm{Pt}(\mathrm{Cu})$ deposit is much rougher than the $\mathrm{Pt}(\mathrm{Co})$ one (the difference in the morphology of the final products is much more pronounced than that of the original $\mathrm{Cu}$ and $\mathrm{Co}$ deposits). Also the composition change of the as prepared $\mathrm{Pt}(\mathrm{Cu})$ catalyst when activated by anodic polarization, points to the anodic dissolution of many uncovered $\mathrm{Cu}$ areas, which in turn indicates the slow/incomplete reaction of $\mathrm{Cu}$ layers with $\mathrm{Pt}$. However, following repetitive potential scans between the hydrogen and oxygen evolution potential limits, both $\mathrm{Pt}(\mathrm{M})$ (and $\mathrm{Au}(\mathrm{M})$ ) catalysts obtained a protective $\mathrm{Pt}$ (or $\mathrm{Au}$ ) shell by the dissolution of uncovered $\mathrm{M}$ areas and the rearrangement/surface segregation of $\mathrm{Pt}(\mathrm{or} \mathrm{Au})$, as indicated by the fact that the surface electrochemistry of these layers in acid is very similar qualitatively to that of bulk $\mathrm{Pt}$ (or $\mathrm{Au}$ ) (see Figure 4A,B [102]).
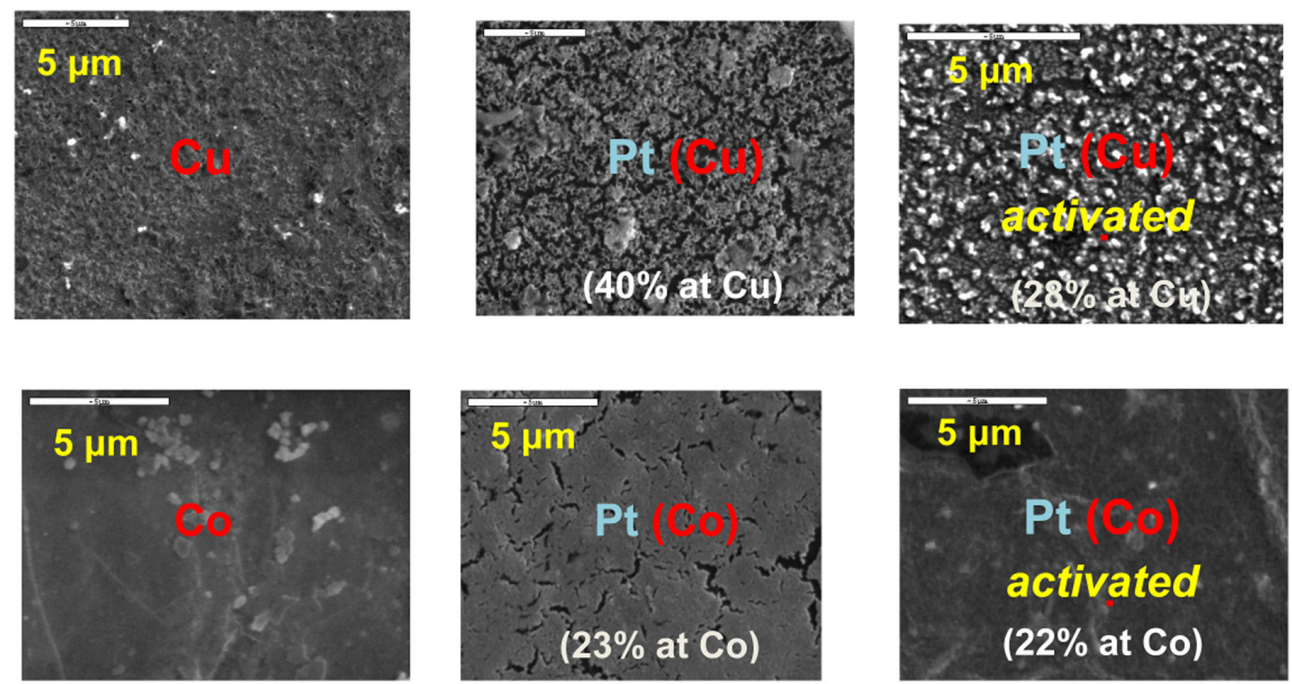

Figure 3. Scanning Electron Microscope (SEM) micrographs of $\mathrm{Cu}$ and Co electrodeposits on a GC substrate, $\mathrm{Pt}(\mathrm{Cu})$, and $\mathrm{Pt}(\mathrm{Co})$ layers formed via galvanic replacement and the same layers after exposure to positive potentials for electrochemical etching of uncovered $\mathrm{Cu}$ and $\mathrm{Co}$ (Reproduced with permission from [101]. Copyright 2007, Elsevier; Reproduced with permission from [103]. Copyright 2008, Elsevier). First row, left to right: $\mathrm{Cu}, \mathrm{Pt}(\mathrm{Cu})$, activated $\mathrm{Pt}(\mathrm{Cu})$; Bottom row, left to right: $\mathrm{Co}, \mathrm{Pt}(\mathrm{Co})$, activated $\mathrm{Pt}(\mathrm{Co})$. The composition depicted corresponds to the atomic percentage of $\mathrm{Cu}$ or $\mathrm{Co}$ in the bimetallic $\mathrm{Pt}(\mathrm{Cu})$ or $\mathrm{Pt}(\mathrm{Co})$ layers, as measured by Energy Dispersive X-ray Spectroscopy (EDS). 

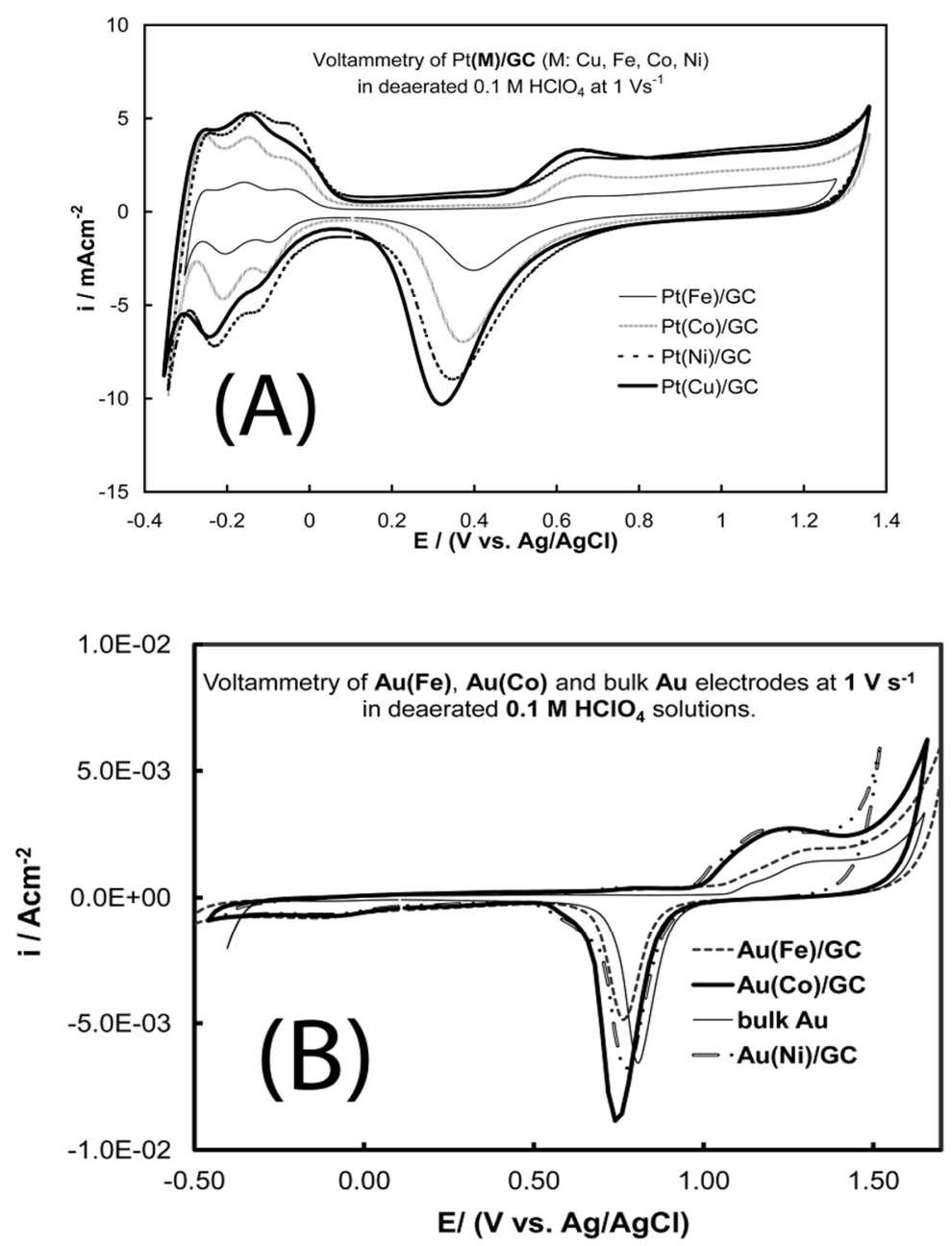

Figure 4. Cyclic voltamograms (stabilized picture) of bimetallic layer electrodes prepared by galvanic replacement obtained in deaerated $0.1 \mathrm{M} \mathrm{HClO}_{4}$ solutions at a scan rate of $1 \mathrm{~V} \cdot \mathrm{s}^{-1}$ : (A) $\mathrm{Pt}(\mathrm{M})$ electrodes where $\mathrm{M}$ is $\mathrm{Cu}, \mathrm{Fe}, \mathrm{Co}$, Ni (Reprinted with permission from [102]. Copyright 2008, Elsevier); (B) $\mathrm{Au}(\mathrm{M})$ electrodes where $\mathrm{M}$ is as in (A) (Reprinted with permission from [101]. Copyright 2007, Elsevier).

Following the macroscopic-electrochemical proof of a Pt or Au skin in these $\mathrm{Pt}(\mathrm{M})$ and $\mathrm{Au}(\mathrm{M})$ bimetallics, the question arising is whether these metals are restricted to the outer layers of the bimetallic layers or they enter the core of the catalyst too. The answer may be given by sputter-etch Auger Electron Spectroscopy (AES), which can provide the elemental composition depth profile of the deposits. Figure 5A,B show such profiles for $\mathrm{Pt}(\mathrm{Cu})$ and $\mathrm{Pt}(\mathrm{Ni})[67,102]$; it can be seen that, although $\mathrm{Pt}$ is preferentially located on the outer surface, it also penetrates the core of the deposit, down to the substrate (in line with a morphology more reminiscent of that depicted at the bottom of Figure 2). However, the fact that a signal from $\mathrm{M}(\mathrm{Cu}$ or $\mathrm{Ni}$ in the examples of Figure 5) could be obtained even before sputtering $[67,102]$ means that the Pt outer shell is thin enough for the Auger electrons of $\mathrm{M}$ to escape and be detected; in fact, back of the envelope calculations [67], taking into account the inelastic mean free path of Auger electrons of the core metal $(\mathrm{Cu}, \mathrm{Ni}, \mathrm{Co}, \mathrm{Fe}, \mathrm{Pb})$ and the atomic dimensions of $\mathrm{Pt}$, point to the outer shell consisting of no more than four Pt monolayers. This is very important since any electronic and geometric effects of the underlayers of $\mathrm{M}$ on the Pt overlayers cannot be extended beyond a few monolayers [149]. Finally, grazing incidence XRD experiments of these model deposits indicate a significant degree of Pt-M alloying within the bimetallic layers (deduced by a shift of the Pt peaks) [106]. 

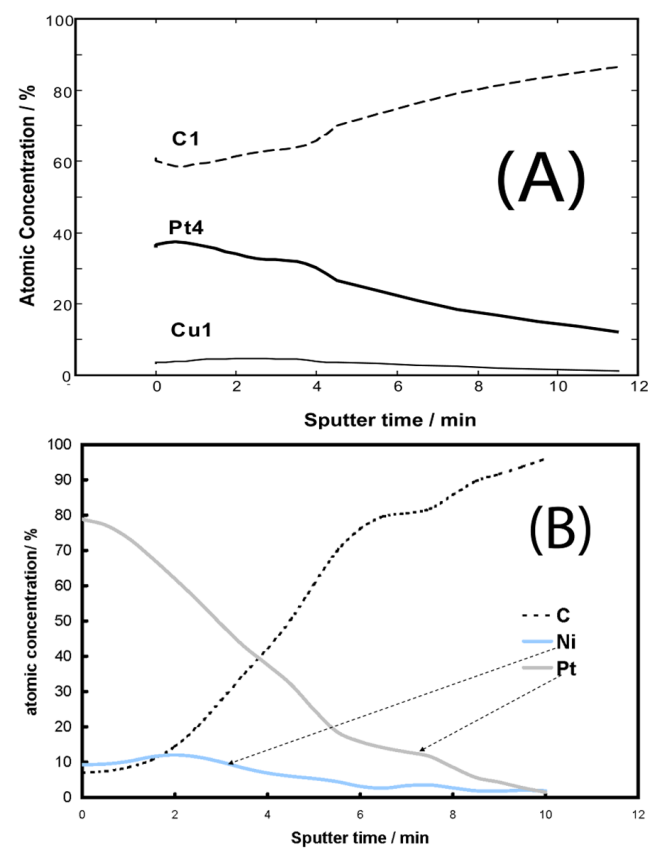

Figure 5. Sputter-etch Auger Electron Spectroscopy (AES) analysis of Pt-based bimetallic layers prepared by galvanic replacement: (A) Depth profile of a $\mathrm{Pt}(\mathrm{Cu})$ deposit (Reproduced with permission from [102]. Copyright 2007, Elsevier); (B) depth profile of a $\mathrm{Pt}(\mathrm{Ni})$ deposit (Adapted to exclude results of the first layer due to adventitious C contamination, with permission from [67]. Copyright 2010, American Chemical Society).

For practical applications, electrocatalysts have to be in nanoparticle form and, in many fuel cell applications, supported on high surface area carbons. Electrodeposition of the less noble metal $\mathrm{M}$ onto carbon or of the upd monolayer on noble-metal decorated carbon particles is one of the routes for preparing the precursor $\mathrm{M} / \mathrm{C}$ or upd $/ \mathrm{M}_{\text {noble }}^{\prime} / \mathrm{C}$ particles; these can be transformed to the bimetallic $\mathrm{M}_{\text {noble }}(\mathrm{M}) / \mathrm{C}$ or $\mathrm{M}_{\text {noble }}\left(\mathrm{M}_{\text {noble }}^{\prime}\right) / \mathrm{C}$ by reaction with the galvanic replacement solution (see, for example, [90,119]). Simpler routes for sacrificial $\mathrm{M}$ metal deposition on $\mathrm{C}$ particles include chemical reduction of $\mathrm{M}$ ions by a reducing agent (e.g., $\mathrm{NaBH}_{4}$ or $\mathrm{EG}$ (ethylene glycol) in a slurry of the carbon powder (see, for example, $[68,108,150]$ ) and the more delicate electroless deposition of $\mathrm{M}$ on $C[107,110]$. A schematic diagram of this preparation process of $\mathrm{Pt}(\mathrm{Cu}) / \mathrm{C}$ catalysts is depicted in Figure 6.

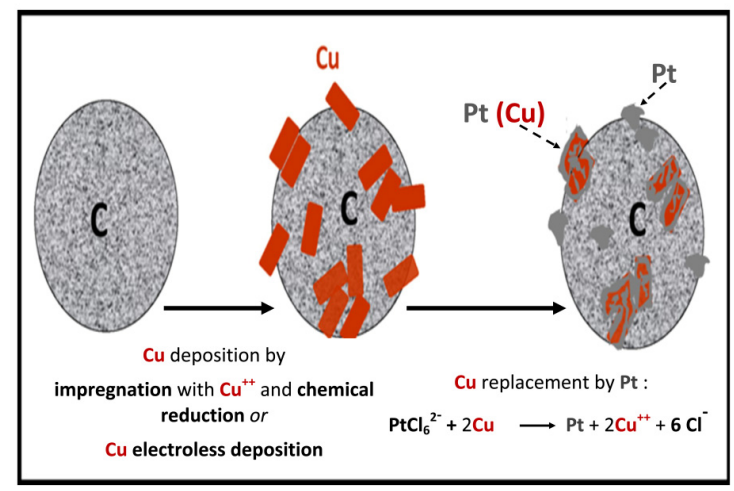

Figure 6. Schematic representation of the formation and morphology of "platinized" Cu nanoparticles supported on carbon particles, $\mathrm{Pt}(\mathrm{Cu}) / \mathrm{C}$, prepared by galvanic replacement. 
As pointed out by Podlovchenko and co-workers [119] and Sotiropoulos and co-workers [68,107,108], in such systems the noble metal (here $\mathrm{Pt}$ ) is expected to deposit not only on sacrificial $\mathrm{M}$ islands (here $\mathrm{Cu}$ ) but also on nearby bare $\mathrm{C}$ locations; this is because the substrate is an electronic conductor and electrons released by the dissolution of $\mathrm{Cu}$ can travel to nearby locations where $\mathrm{Pt}$ ions may be reduced and deposited as metallic Pt. Note that this effect is expected to occur at a lower extent in catalysts prepared via the $\mathrm{Cu}$ upd method since the whole process of replacing a single monolayer is restricted both in time and space; also, in principle, it should be absent if the support of $\mathrm{M}$ is an insulator or semiconductor (e.g., $\mathrm{TiO}_{2}$ or $\mathrm{WO}_{3}$, as in $[111,112,151]$ ) or if the particles are prepared before the addition of the support (see, for example, [152].

Figure 7A,B presents $\mathrm{Pt}(\mathrm{Cu})$ and $\mathrm{Pt}(\mathrm{Ni})$ nanoparticles resulting from the (partial) galvanic replacement of electrolessly prepared $\mathrm{Cu} / \mathrm{C}$ and $\mathrm{Ni} / \mathrm{C}$ precursors $[107,110]$. The TEM photographs reveal aggregates 10-20 nm large for $\mathrm{Pt}(\mathrm{Cu})$ and smaller than $10 \mathrm{~nm}$ for $\mathrm{Pt}(\mathrm{Ni})$, which are larger than those of the commercial $\mathrm{Pt} / \mathrm{C}$ catalyst shown in Figure 7C.
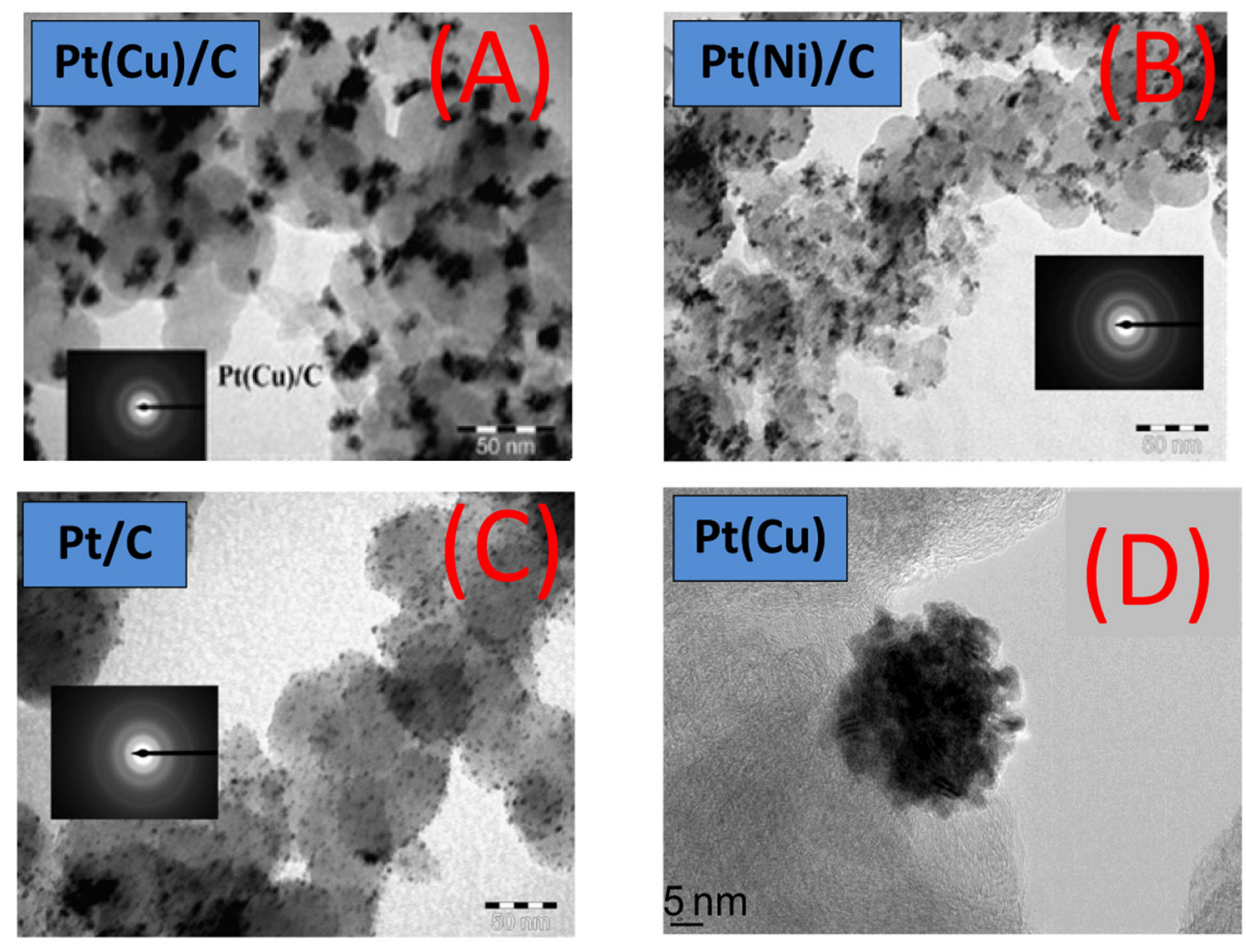

Figure 7. Transmission electron microscopy (TEM) micrographs of supported and unsupported Pt-based nanoparticle catalysts: $(\mathrm{A}) \mathrm{Pt}(\mathrm{Cu}) / \mathrm{C}$ catalyst prepared by galvanic replacement of electrolessly prepared $\mathrm{Cu} / \mathrm{C}$ precursors (Reprinted with permission from [110]. Copyright 2014, Springer); (B) $\mathrm{Pt}(\mathrm{Ni}) / \mathrm{C}$ catalyst prepared in a similar to (A) manner (Reprinted with permission from [107]. Copyright 2013, Springer); (C) commercial Pt/C catalyst (E-TEK, Somerset, NJ, USA) (Reprinted with permission from [107]. Copyright 2013, Springer; Reprinted with permission from [110]. Copyright 2014, Springer); (D) unsupported $\mathrm{Pt}(\mathrm{Cu})$ nanoparticle formed by galvanic replacement of $\mathrm{Cu}$ particles prepared by hydrogen annealing of $\mathrm{Cu}$ oxide particles [152]. (Scale bars correspond to $50 \mathrm{~nm}$ (A)-(C) and $5 \mathrm{~nm}(\mathbf{D})$.)

XRD data for these $[107,110]$ and similar $[68,108]$ catalysts revealed an apparently Pt-rich alloy. The latter has usually a higher Pt content than that of the entire catalyst as estimated by EDS analysis $[107,108,110]$, which could be the result of low degree of alloying (with pure $\mathrm{Cu}[107,108,110]$ pockets within the core of the catalyst). On the contrary, EDS and XRD analysis of the $\mathrm{Pt}(\mathrm{Cu})$ prepared in [68] points either to the coexistence of $\mathrm{Pt}$ pockets within the bimetallic particles or/and pure $\mathrm{Pt}$ deposits at nearby $\mathrm{C}$ locations (according to the reasoning of the previous paragraph). Incomplete 
alloying may also be the reason why no significant shift in Pt X-ray photoelectron spectroscopy (XPS) peaks has been observed $[68,107,108,110]$. This, however, does not exclude the possibility of significant modification of the outer Pt skin electronic properties (at locations where it is thin enough) by the underlying core metal, since XPS may not be surface sensitive enough to probe the outer layers. Furthermore, as pointed out in [153], neither conventional XRD nor XPS can give decisive information about nanoparticles of a non-homogeneous composition. A review of the various characterization techniques for core-shell nanoparticles and the information they provide is due to Koper and co-workers [154]. An excellent paper presenting the results of state-of-the-art microscopic and spectroscopic techniques (High-angle annular dark-field scanning transmission electron microscopy (HAADF-STEM), STEM-electron energy loss spectroscopy (STEM-EELS), STEM-energy dispersive X-ray spectroscopy (STEM-EDS), Extended X-ray absorption fine structure (EXAFS)) for the characterization of bimetallic nanoparticles prepared by galvanic replacement is due to Adzic and co-workers [90] while the exciting real time observation of Pd deposition on Ag nanoparticles by in situ liquid-cell electron microscopy has been reported by Sutter and co-workers [155].

Finally, one should keep in mind that a large number of works are based on the separate preparation of the bimetallic particles without the presence of a support (which can be added at

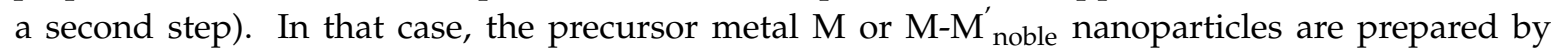
one of the common metal nanoparticle preparation techniques or their combination; these include hydrothermal reduction in the presence of polyols or $\mathrm{NaBH}_{4}$ and high temperature hydrogen annealing (see, for example, $[156,157])$. Figure 7D shows such a $\mathrm{Pt}(\mathrm{Cu})$ nanoparticle, prepared by the galvanic replacement of $\mathrm{Cu}$ particles synthesized by hydrogen annealing of $\mathrm{Cu}$ oxides [152] and subsequently supported/mixed with $C$ particles.

\section{Electrochemical Reactions at Poly-Metallic Catalysts Prepared by Galvanic Reaction}

\subsection{Oxygen Reduction}

The oxygen reduction reaction (ORR) is of paramount importance for many electrochemical energy conversion applications such as those of fuel cells and batteries (see, for example, [158]). To improve the slow kinetics of oxygen reduction [159] in low and moderately elevated temperature fuel cells, Pt-based catalysts (the common choice in acid electrolytes) have been modified by the addition of other noble metals (e.g., Au, Pd etc.) or other transition metals (mainly $\mathrm{Cr}, \mathrm{Fe}, \mathrm{Co}$, and $\mathrm{Ni}$ ) to binary, ternary or even tertiary composite materials (see, for example, [160-162]). In line with this, core-shell polymetallic catalysts prepared by galvanic replacement have also been proposed.

The most extensive and successful work in the field is due to Adzic and co-workers, who prepared finely tuned Pt monolayer catalysts with very high ORR intrinsic catalytic activity and the highest reported mass specific activity [65,66,79,81-83,86,88-92,96,163-180]. In more detail, they have predicted theoretically (by means of Density Functional Theory (DFT) calculations) and confirmed experimentally that the most active catalyst for ORR is based on a Pt skin and a Pd-based core [81] which can be further improved by the use of a mixed Pt-noble metal skin and can reach an enhancement of mass activity in the 3-20-fold range [82]. An alternative improvement of this system is to use a Pt skin and a Pd-Fe or Pd-Co core [163-165]. Another class of similar catalysts includes materials with a Pt skin and an Ir-based core (Ir-Co, Ir-Fe, Ir-Ni, Ir-Re, Ir-Cu, Ir-Pd) [96,166-170,180]. In an attempt to offer an improved non-Pt cathode, they also proposed Pd skin-Pd-based core catalysts [171-173]. Finally, to improve core stability, they proposed the use of Au interlayers [174-177] or the transformation of core metals to their nitrides [178,179].

Kokkinidis and co-workers and Sotiropoulos and co-workers have also tested their $\mathrm{Pt}(\mathrm{M})$ and $\mathrm{Au}(\mathrm{M})(\mathrm{M}: \mathrm{Pb}, \mathrm{Cu}, \mathrm{Fe}, \mathrm{Co}, \mathrm{Ni})$ particulate deposits on GC as oxygen cathodes in acid and have found in some cases a moderate enhancement in their ORR activity per electroactive area $[75,76,101,103,105]$. (They have also pointed out the importance of the starting potential in voltammetric experiments in accessing ORR electrocatalytic activity at Pt-based electrodes [105].) Practical $\mathrm{Pt}(\mathrm{Cu}) / \mathrm{C}$ catalysts 
prepared by this approach on high surface area carbons also exhibited a moderate intrinsic activity enhancement and a comparable/slightly improved mass specific activity for ORR when compared to commercial $\mathrm{Pt} / \mathrm{C}$ catalysts [68]. The moderate improvement in ORR activity for this type of catalysts is due to the fact that the skin is expected to be thicker than that of the Adzic-type ones (see Figure 1); also, the core is expected to contain rather low quantities of $\mathrm{M}$ (see also the AES experimental evidence discussed in the previous section), so that the overall favorable modification of Pt properties is attenuated.

Following or in parallel with these studies on supported poly-metallic catalysts, a number of other papers have appeared on supported and un-supported poly-metallic nanoparticles prepared by galvanic replacement and proposed as ORR catalysts. These include Pt-based nanoparticles (e.g., $\mathrm{Pt}(\mathrm{Cu}), \mathrm{Pt}(\mathrm{CuCo}), \mathrm{Pt}(\mathrm{Ni})$, and $\mathrm{Pt}(\mathrm{Ag})$ [181-190]) and $\mathrm{Pd}$ - or Au-based nanoparticles, in some cases in combination with $\mathrm{Pt}$ (see, for example, [191-198]).

The modification of the catalytic properties of Pt overlayers (and other noble metals, $\mathrm{M}_{\text {noble, }}$, that have a relatively large Wigner-Seitz atomic radius and high elegronegativity) when they are in contact with early transition metal $\mathrm{M}$ underlayers (of a smaller radius and electronegativity) has been widely attributed to the downward shift in Pt d-band energy centre, $\varepsilon_{\mathrm{d}}$. This shift has been predicted in the seminal work of Nørskov and co-workers $[143,144]$ and is known to decrease the adsorption strength of the overlayers towards small species such as $\mathrm{O}, \mathrm{OH}, \mathrm{H}$, and $\mathrm{CO}$ entities. It has been confirmed experimentally directly by high resolution ultraviolet photoelectron spectroscopy (UPS) measurements of d-electron energy $[199,200]$ and indirectly by XPS measurements that confirmed a down-shift of core electron energy levels [201].

With respect to the higher ORR catalytic activity of $\mathrm{Pt}(\mathrm{M})$ electrodes, two interpretations have been offered. Ross, Markovic, Stamenkovic, and co-workers [199,200,202-206] propose the reduction of Pt-O and $\mathrm{Pt}-\mathrm{OH}$ (intermediates formed by oxygen adsorption) as the rate determining step of ORR. It is the weakening of the $\mathrm{Pt}-\mathrm{O}$ bonds at $\mathrm{Pt}(\mathrm{M})$ systems that facilitates the removal of $\mathrm{O}$ adsorbed species and increases the rate of ORR. Contrary to these views, Watanabe and co-workers have found an increase in $\mathrm{Pt}-\mathrm{O}$ coverage at $\mathrm{Pt}(\mathrm{Fe})$ layers [207], which they interpret by an increase in Pt d-electron back-donation from a higher Fermi level (with respect to the down-shifted $e_{d}$ and core energy levels [201]) to oxygen $\pi^{*}$ orbitals, a trend that increases the scission of $\mathrm{O}-\mathrm{O}$ bonds and hence oxygen chemisorption and its reduction.

\subsection{Methanol, Formic Acid, and Ethanol Oxidation}

Direct methanol fuel cells, although not yet a viable solution for large scale applications, are of technological relevance for portable and micro-fuel cells in direct methanol fuel cells. Hence, a large number of papers are devoted to methanol electrooxidation in search for efficient anodes (see, for example, [208,209]). In search for efficient electrocatalysts that would remedy the Pt-based anode poisoning by a carbonaceous intermediate (most likely CO), many poly-metallic systems have been studied both in the form of ad-atom surface layers on Pt [210,211] and binary [212-214] or ternary [212,215] Pt alloys. It is now accepted that the best bi-metallic system is that of Pt-Ru but the high cost of Ru has made the identification of other metals M that increase Pt or Pt-Ru activity towards MOR very important.

Poly-metallic Pt-based catalysts prepared by galvanic replacement have been tested in methanol oxidation both for practical reasons (increased Pt utilization and modification of its electronic properties) and for fundamental research (the pure Pt shell of some of these systems ensures that only $\mathrm{Pt}-\mathrm{M}$ electronic and lattice mismatch interactions will be operative and no synergistic or third-body effects of $\mathrm{M}$ will be present).

$\mathrm{Pt}$ monolayers/submonolayers prepared by the the $\mathrm{Cu}$ upd replacement technique onto $\mathrm{Au}, \mathrm{Ru}$, $\mathrm{NbO}_{2}$ and $\mathrm{PdCu}[94,216,217]$ have been used for methanol oxidation by Adzic and co-workers and the resulting electrode surfaces have been proven more efficient than Pt. The same authors have also prepared electrodes by the replacement of $\mathrm{Cu}$ and $\mathrm{Pb}$ bulk deposits [218] by $\mathrm{Pt}$ or $\mathrm{Pt}-\mathrm{Ru}$ layers and 
have prepared catalysts with an up to 10-fold increase in MOR activity with respect to commercial $\mathrm{Pt}-\mathrm{Ru} / \mathrm{C}$ catalysts.

Podlovchenko and co-workers have also tried the replacement of $\mathrm{Cu}$ upd by $\mathrm{Pt}$ on $\mathrm{Pd}$ and $\mathrm{Au}$ surfaces $[125,126]$ as well as the partial replacement of $\mathrm{Cu}$ coatings (mainly electrodeposits) on carbon substrates $[13,70,117,119]$; depending on preparation conditions they found a moderate or small change in MOR activity at $\mathrm{Pt}(\mathrm{Cu})$ electrodes. However, the same authors have reported significant enhancement of MOR rates at $\mathrm{Pt}$ and $\mathrm{Pd}$ electrodes prepared by the partial replacement of $\mathrm{H}$ atoms from hydrogen-containing Mo bronzes [69,118,127,128,219].

Sotiropoulos and co-workers have found a very significant enhancement in the intrinsic MOR activity of $\mathrm{Pt}(\mathrm{Cu})$ layers on glassy carbon substrates with respect to $\mathrm{Pt}(\mathrm{Pb}), \mathrm{Pt}(\mathrm{Co}), \mathrm{Pt}(\mathrm{Ni})$, and pure Pt layers $[67,100])$. (The same workers have proven the applicability of the method to produce the MOR oxidation benchmark catalytic material of $\mathrm{PtRu}$ in the form of $\mathrm{Pt}-\mathrm{Ru}(\mathrm{Ni})$ layers [109]). A similar enhancement of MOR activity (together with a noticeable shift of $\mathrm{CO}$ electrooxidation to less positive potentials) was recorded at $\mathrm{Pt}(\mathrm{Ni}) / \mathrm{C}$ and $\mathrm{Pt}(\mathrm{Cu}) / \mathrm{C}$ nanoparticles with respect to commercial $\mathrm{Pt} / \mathrm{C}$ ones $[107,108,152]$; however, the mass specific activity of these catalysts is similar to that of commercial catalysts due to relatively large particles and rather small surface area. They have also found an increase of intrinsic MOR rates at $\mathrm{Pt} / \mathrm{TiO}_{2}$ and $\mathrm{Pt} / \mathrm{WO}_{3}$ layers or particles and a further increase upon UV and/or visible light illumination [111,151].

Many other papers reporting bimetallic or tri-metallic, solid or hollow nanoparticles, prepared by galvanic replacement and tested as MOR anodes, have appeared in the literature; examples include $\mathrm{Pt}(\mathrm{Co})$ [220-222], $\mathrm{Pt}(\mathrm{Fe})$ [223], $\mathrm{Pt}(\mathrm{Au})$ [224], $\mathrm{Pt}-\mathrm{Pd}(\mathrm{Cu})$ [225], $\mathrm{Pt}\left(\mathrm{Cu}_{2} \mathrm{O}\right)$ [226], $\mathrm{Pd}-\mathrm{Ni}(\mathrm{Ni})$ [227] and $\mathrm{Pt}(\mathrm{Ag})$ [228-232] nanoparticles.

The increase in MOR catalytic activity that has been observed in most of the above multicomponent catalysts can be interpreted according to the effect(s) of the second metal/metal oxide on the catalyst properties, as reviewed by Ishikawa and co-workers [233]. The second metal can increase the reaction rate by synergy (either disrupting the Pt reaction sites and the adsorption of poisonous intermediates - the "third-body effect" — or by hosting oxygenated species that remove the poisons) or via an electronic effect on Pt or Pd (either a "ligand" effect due to a difference in electronegativity or by a strain effect due to differences in atom size [143,144]). In those systems that the second metal/metal oxide is also on the surface (e.g., Pt-Ru, Pt- $\mathrm{MO}_{x}, \mathrm{Pd}-\mathrm{MO}_{x}, \mathrm{Pt}-\mathrm{Au}, \mathrm{Pt}-\mathrm{TiO}_{2}$, $\mathrm{Pt}-\mathrm{WO}_{3}$ catalysts) both the synergistic and electronic effects are operative (with the former expected to dominate) while in the case of a $\mathrm{Pt}$ (or Pd) skin, only the electronic effect is present. In the latter case, when the second metal is less electronegative and of a smaller atom radius than $\mathrm{Pt}(\mathrm{or} \mathrm{Pd}$ ) then the down-shift of the $e_{d}$ level of $\mathrm{Pt}$ (or Pd) is expected to decrease their adsorption affinity for both the chemisorbed reactant (methanol) and the poisonous intermediate (CO); this in turn leads to an optimum adsorption affinity needed for maximum MOR rates, which has been claimed to be supplied by a Cu-rich core [67].

Formic acid is recognized as a liquid fuel alternative to methanol since it is safer, it does not pose fuel cell membrane crossover problems, and has a higher oxidation potential, trailing only in volumetric energy density (see, for example, [234,235]). In a search of bimetallic or trimetallic catalysts that show improved activity for formic acid oxidation (FAO) with respect to the best electrode materials of $\mathrm{Pd}$ and $\mathrm{Pt}$, galvanic replacement has been used as preparation route (see, for example, [126,236-253]). These include Pt(Ag) and Pd(Ag) [232,241,244], PdAu and PtAu [237,238,245,246,252], PdPb [239], $\mathrm{Pt}(\mathrm{Bi})$ [124], $\mathrm{Pd}(\mathrm{Ni})$ [249] and $\mathrm{Pd}(\mathrm{Cu})[247,248]$ bimetallics as well as $\mathrm{Pd}(\mathrm{CuFe})[250]$ and $\mathrm{Pt}(\mathrm{PdFe})$ [253] trimetallic systems. The performance improvement of these systems is interpreted in terms of $\mathrm{CO}$ poison desorption from $\mathrm{Pt}$ in the presence of other metals (where the dehydration mechanism of FAO is operative [235]), and in terms of carbonaceous intermediates removal in the case of $\mathrm{Pd}$ (where the dehydrogenation mechanism prevails [235]).

Ethanol is another candidate for small-scale liquid fuel cells, its main advantages being non-toxicity, natural availability, and high power density (see, for example, [254,255]). Many catalysts 
for ethanol oxidation reaction (EOR) have been prepared by the galvanic replacement method (see, for example, [256-274]). Bimetallic systems include PtAu [256,259,260,270], Pd(Ag) [261,266,272-274] and $\mathrm{Pt}(\mathrm{Cu})$ [260]. Ternary catalysts for EOR prepared by galvanic replacement include $\mathrm{PtAu}(\mathrm{Cu})$ [260], $\mathrm{PtPd}(\mathrm{Ni})$ [262], $\mathrm{PtPb}(\mathrm{Ni})$ [263], $\mathrm{PtRu}(\mathrm{Cu})$ [264], $\mathrm{Pt}(\mathrm{PdAu})$ [267], $\mathrm{PdAg}(\mathrm{Au})$ [268] and $\mathrm{PdRu}\left(\mathrm{Cu}_{2} \mathrm{O}\right)$ [271] (note that a metal can also be replaced from one of its oxides, as discussed in Section 2.3)

\subsection{Hydrogen Evolution and Oxidation}

The Hydrogen Evolution Reaction (HER) and the reverse reaction of Hydrogen Oxidation Reaction (HOR) are very important in electrochemical energy storage and conversion since $\mathrm{H}_{2}$ produced by electrolysis of water in electrolyzers is the fuel feed in fuel cells $[275,276]$. Both electrodes used for HER in alkaline media (e.g., $\mathrm{Ni}$ ) and in acid media (e.g., $\mathrm{Pt}$ ) have been modified by other metals via a galvanic replacement process that introduces a second metal to the system.

Trasatti and co-workers $[139,140]$ and Musiani and co-workers $[71,129,132]$ have modified Ni substrates with $\mathrm{Ru}$ and Ir nuclei and porous or three-dimensional Ni cathodes with Ir or Pt nuclei respectively. They have pointed out the critical effect of the state of Ru and Ir complexes, as well as the presence/absence of oxygen and $\mathrm{pH}$, on the galvanic replacement process and have found that the modified cathodes showed enhanced HER performance in alkaline solutions (with respect to plain $\mathrm{Ni}$ ). This finding is to be expected since these noble metals ( $\mathrm{Pt}, \mathrm{Ir}, \mathrm{Ru})$ are better catalysts for HER than Ni. Nevertheless, it is of practical importance that efficient HER cathodes with very low precious metal loadings can be prepared by a relatively simple galvanic replacement process.

Conflicting results have been reported for HER in acidic media at $\mathrm{Pt}(\mathrm{M})$ electrodes with a continuous $\mathrm{Pt}$ skin. In more detail, increased activity of $\mathrm{Pt}(\mathrm{Ag})$ hollow nanocubes [277] and $\mathrm{Pt}(\mathrm{Cu})$, $\operatorname{Pd}(\mathrm{Cu})$, or $\operatorname{PtPd}(\mathrm{Cu})$ deposits on $\mathrm{Cu}$ particles or foams [278-281] has been reported, but that was only based on current densities per substrate geometric area or per catalyst mass, hence they might not have been representative of the inherent activity of the systems. However, in a recent paper a trimetallic $\mathrm{Pt}(\mathrm{CuNi})$ catalyst anchored on carbon nanofibers was shown to possess both high mass specific activity and enhanced intrinsic activity for HER (per electroactive surface area) with respect to pure $\mathrm{Pt}$ [282]. (One should note, however, that unusual Pt surface electrochemistry was recorded in that work and, also, $\mathrm{Cu}$ and $\mathrm{Ni}$ were found to be on the surface, possibly offering direct synergism to Pt rather than simple electronic modification.)

On the other hand, Papadimitriou et al. found that $\mathrm{Pt}(\mathrm{M})$ catalytic layers $(\mathrm{M}: \mathrm{Fe}, \mathrm{Co}, \mathrm{Ni}, \mathrm{Cu})$ [102] with a continuous $\mathrm{Pt}$ shell are characterized by decreased HER intrinsic activity. This is in line with results obtained at $\mathrm{Pt}(\mathrm{Ag})$ [283], $\mathrm{Pt}-\mathrm{Ni}$ [284] and $\mathrm{Pd}(\mathrm{Fe})$ [285] electrodes. For $\mathrm{Pt}$ it can be explained in a qualitative manner by the expected down-shift of the Pt $\mathrm{d}$-electron band energy level, $\mathrm{e}_{\mathrm{d}}$ (due to the presence of an underlayer containing smaller and less electronegative atoms), which in turn decreases $\mathrm{Pt}$ adsorption affinity $[143,144]$; the latter leads to a $\mathrm{Pt}(\mathrm{M})-\mathrm{H}_{\mathrm{ads}}$ bond weakening as compared to $\mathrm{Pt}-\mathrm{H}_{\mathrm{ads}}$. Since HER activity is known to vary with metal-hydrogen bond strength in a volcano plot manner [286] and Pt lies very close to the top of the plot, any significant modification of its properties is likely to have an adverse effect on HER. The decreased hydrogen adsorption strength of $\mathrm{Pt}-\mathrm{Cu}$, $\mathrm{Pt}-\mathrm{Ni}, \mathrm{Pt}-\mathrm{Fe}$, and $\mathrm{Pt}-\mathrm{Co}$ surface or near surface alloys has also been theoretically predicted based on DFT calculations [287-290]. Nevertheless, in [287] improved HER activity has been found for the Pt-Bi surface alloy, both theoretically and experimentally. The decreased HER activity of $\mathrm{Pt}(\mathrm{Cu}), \mathrm{Pt}(\mathrm{Fe})$, $\mathrm{Pt}(\mathrm{Co})$, and $\mathrm{Pt}(\mathrm{Ni})$ materials, although detrimental for their potential use as hydrogen producing cathodes, makes them candidate materials for hydrogenation reactions and for borohydride oxidation (see also below).

Finally, as far as HOR is concerned, Adzic and co-workers report increased mass and intrinsic activity at Pt submonolayers/shells deposited on Au or Ru substrates or nanoparticles $[79,291]$ via the galvanic replacement of $\mathrm{Cu}$ upd layers. 


\subsection{Oxygen Evolution}

Oxygen evolution reaction (OER) is important in many industrial applications as the anode reaction of the electrochemical cell and in particular in water electrolysis for hydrogen production at the cathode [292]; in cases that electrolysis is performed under acidic conditions (as in Solid Polymer Electrolyte, SPE, electrolyzers) metals/oxides more stable than $\mathrm{Pt}$ (such as $\mathrm{Ir} / \mathrm{IrO} \mathrm{I}_{2}$ ) are used.

There are very few papers testing catalysts prepared by galvanic replacement as OER anodes and these include $\mathrm{Pt}(\mathrm{Co})$ [293] and $\operatorname{Ir}(\mathrm{Cu})$ [294-296] bimetallic electrode systems that they show improved mass specific activity with respect to the precious metal (Pt or Ir).

Although catalyst particles with an $\mathrm{IrO}_{2}$ shell and an $\mathrm{Ir}-\mathrm{Ni}$ core have been reported by Strasser and co-workers to be excellent OER anodes, the initial Ir-Ni binary precursor was prepared on C or antimony-doped tin oxide by chemical reduction [297,298] or co-sputtering on Ti and Si substrates [299] (not by galvanic replacement); the precursor was subsequently electrochemically or thermally treated so that de-alloying and/or Ir surface segregation occurred, leading to the formation of an $\mathrm{IrO}_{2}$ skin (due to anodization or heating). Papaderakis et al. [113] introduced $\mathrm{IrO}_{2}(\mathrm{Ir}-\mathrm{Ni}) \mathrm{OER}$ catalysts where the initial $\operatorname{Ir}(\mathrm{Ir}-\mathrm{Ni})$ material was prepared by galvanic replacement and was further electro-oxidized to form an $\mathrm{IrO}_{2}$ skin over the $\mathrm{Ir}(\mathrm{Ir}-\mathrm{Ni}$ ) core (see Figure 8).

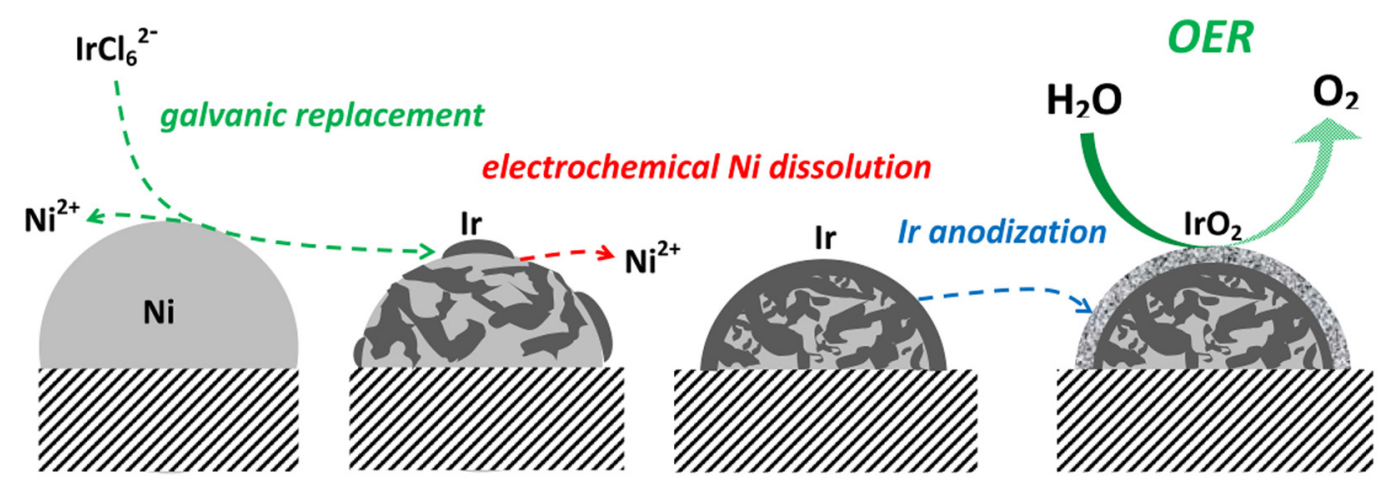

Figure 8. Schematic representation of the formation and morphology of $\mathrm{IrO}_{2}$-coated $\mathrm{Ir}(\mathrm{Ni}) / \mathrm{GC}$ deposits, prepared by galvanic replacement of Ni by Ir, followed by anodic growth of $\mathrm{IrO}_{2}$ on the Ir shell. (Reproduced with permission from [113]. Copyright 2016, American Chemical Sociely).

They recorded moderately higher OER currents (per $\mathrm{IrO}_{2}$ electroactive area) than plain $\mathrm{IrO}_{2} / \mathrm{Ir}$ electrodes and attributed that to an electronic and geometric effect of core $\mathrm{Ni}$ to the $\mathrm{IrO}_{2}$ shell, resulting in a destabilization of Ir-OH bonds, which is the rds of OER.

\subsection{Borohydride Oxidation}

Although not likely to replace $\mathrm{H}_{2} / \mathrm{O}_{2}$ fuel cells in large-scale and automobile applications, direct borohydride fuel cells may find applications in micro-fuel cells [300,301]. Pt has considerable electrocatalytic activity for borohydride oxidation (BOR), but it also causes chemical decomposition of $\mathrm{NaBH}_{4}$ at open circuit while its very low hydrogen evolution overpotential does not allow operation close to the borohydride standard potential (which is lower than that of $\mathrm{H}_{2}$ ); it also shows a low coulombic efficiency since the reaction is completed with the loss of four electrons per molecule. On the other hand, Au is an inferior electrocatalyst but its coulombic efficiency approaches the maximum value, corresponding to the eight-electron reaction pathway $[104,106]$. Bimetallic $\mathrm{Pt}-\mathrm{Au}$ systems are expected to combine the high kinetics of Pt with the high coulombic efficiency of Au [302-304].

The above discussion shows that there is room for the improvement of $\mathrm{Pt}$ (via suppression of borohydride direct hydrolysis and/or of hydrogen evolution and/or an increase of its coulombic efficiency) and of $\mathrm{Au}$ (via improvement of its kinetics). To that direction, bi- and tri-metallic systems have been tested and galvanic replacement has been one of the preparation methods proposed. In 
more detail, improved BOR electrocatalysts include $\mathrm{Au}-\mathrm{Ni}$ surface layers that have been prepared by selective replacement of $\mathrm{Zn}$ from $\mathrm{Zn}-\mathrm{Ni}$ precursor layers [305], $\mathrm{Pt}(\mathrm{Co})$ deposits formed on $\mathrm{Co}_{3} \mathrm{O}_{4}$ nanosheets [306], and hollow Pt nanospheres via the replacement of sacrificial Co nanoparticles [307]. Tegou et al. [106] have reported that platinized nickel or cobalt layers, $\mathrm{Pt}(\mathrm{Ni})$ and $\mathrm{Pt}(\mathrm{Co})$, show a lower BOR onset potential than pure Pt (see Figure 9A) and attributed this to the combined effect of increased chemical hydrolysis of borohydride to hydrogen that is further electrooxidized and hindered electrochemical hydrogen evolution (which increases the rest potential with respect to the thermodynamic equilibrium potential of the reaction). The latter part of the interpretation is in complete accordance with the experimental finding of HER suppression at the same type of $\operatorname{Pt}(\mathrm{M})$ electrodes discussed in Section 5.3.
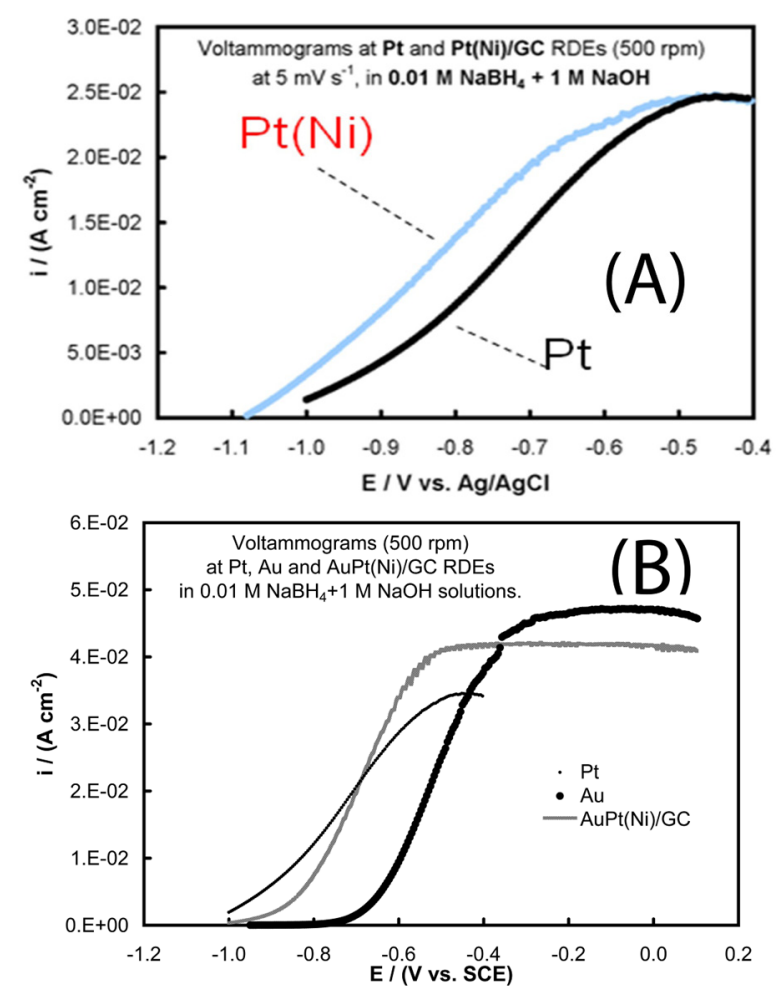

Figure 9. Linear sweep voltamograms (recorded at a $5 \mathrm{mV} \cdot \mathrm{s}^{-1} \mathrm{scan}$ rate) at bi- and tri-metallic layer electrodes, prepared by galvanic replacement, corresponding to borohydride oxidation from $0.01 \mathrm{M}$ $\mathrm{NaBH}_{4}$ solutions in $1 \mathrm{M} \mathrm{NaOH}$ : (A) Pt(Ni) and Pt electrodes (Adapted with permission from [106]. Copyright 2011, Elsevier); (B) PtAu(Ni), Pt and Au electrodes (Reproduced with permission from [104]. Copyright 2009, Elsevier).

The same authors have managed to prepare a tri-metallic $\mathrm{PtAu}(\mathrm{Ni})$ electrode of a mixed $\mathrm{Pt}-\mathrm{Au}$ surface [104], exhibiting the corresponding combination of good catalytic activity and coulombic efficiency (see Figure 9B). XRD measurements confirmed complete PtAu alloying, while surface and BOR electrochemistry proved the desired co-existence of $\mathrm{Pt}$ and $\mathrm{Au}$ on the surface (i.e., the absence of segregation); note that the preparation of PtAu surface alloys is a very difficult task since the two metals are not expected to form a single phase at non-elevated temperatures [308] and, on the other hand, Au will segregate on the surface at elevated temperatures [309].

\subsection{Other Cathodic Reactions}

The use of electrocatalysts of the $\mathrm{M}_{\text {noble }}(\mathrm{M})$ type, prepared by galvanic replacement, as cathodes in neutral or alkaline media, offers the possibility of using electrodes with nuclei of $\mathrm{M}_{\text {noble }}$ on an $\mathrm{M}$ substrate without the need for complete coverage-protection of the latter, since $\mathrm{M}$ (e.g., $\mathrm{Ni}, \mathrm{Cu}$, stainless 
steel) will be stable under these conditions. This means that there is no need for electrochemically dissolving any uncovered areas when $\mathrm{M}$ is in the form of layers or that bulk $\mathrm{M}$ substrates (plates, three-dimensional electrodes, etc.) can be used.

Most of the work in that direction is due to Musiani and co-workers. Apart from using $\operatorname{Ir}(\mathrm{Ni})$ and $\mathrm{Pt}(\mathrm{Ni})$ cathodes for HER $[71,129,132]$, they also expanded their studies to environmental remediation and electroanalysis. In more detail, they proposed the use of $\mathrm{Rh}(\mathrm{Ni})$ catalytic layers on $\mathrm{Ni}$ foams as a cathode for efficient nitrate removal by its reduction [134] and the use of $\mathrm{Rh}(\mathrm{Cu})$ layers on $\mathrm{Cu}$ porous electrodeposits as sensing cathodes for nitrate and nitrite detection [138]. They have also introduced $\mathrm{Ag}(\mathrm{Ni})$ cathodes for the reductive dechlorination of pesticide pollutants [137].

A similar cathodic reaction of an electrosynthetic interest that has been carried out at $\mathrm{Ag}(\mathrm{Ni})$ electrodes is that of the cathodic cleavage of the $\mathrm{C}-\mathrm{Br}$ bond. Vanrenterghem et al. [310] have proven that Ag modified Ni layers and $\mathrm{Ni}$ foams show both higher intrinsic catalytic activity towards benzyl-bromide reduction and higher yields of toluene production during its bulk electrolysis.

\section{Conclusions/Future Avenues}

During the last two decades galvanic replacement has been established as a viable method for the preparation of noble metal $\left(\mathrm{M}_{\text {noble }}\right)$-based electrocatalysts. Advantages, when compared to the most common high temperature annealing or hydrothermal techniques, include:

(i) It is a moderate temperature method, resulting in energy savings and most importantly in limited particle aggregation (thus increased surface area).

(ii) It can lead (especially via its $\mathrm{Cu}, \mathrm{Pb}$, or $\mathrm{H}$ upd replacement variant) to a minimization of noble metal loadings in the polymetallic catalyst, since the noble metal can preferably (or even exclusively) be located at the outer layer(s).

(iii) It is a relatively simple method that involves few steps and chemicals (especially in its variant where a bulk metallic substrate is modified by the more noble metal by simply immersing the former into an ionic solution of the latter).

A critical evaluation of the achievements and the potential of the three main variants of the method namely, the replacement of upd monolayers by $\mathrm{M}_{\text {noble, }}$, the direct replacement of surface layers of nanoparticles of a metal $\mathrm{M}$ and the decoration of bulk structures of the latter with nuclei of $\mathrm{M}_{\text {noble }}$, can be summarized as follows:

(i) The galvanic replacement of upd monolayers is perhaps the most mature method for preparing commercial catalysts and has shown remarkable noble metal mass utilization, especially for oxygen reduction and the $\mathrm{Pt}(\mathrm{Pd})$ system. The only foreseen hurdle is moving the catalyst preparation industry to use the apparatus needed for the electrodeposition of the sacrificial metal upd onto a fluidized electrode of $\mathrm{M}$ or $\mathrm{M} / \mathrm{C}$ particles, that will be subsequently transformed to $\mathrm{M}_{\text {noble }}(\mathrm{M})$ or $\mathrm{M}_{\text {noble }}(\mathrm{M}) / \mathrm{C}$ particles. (The alternative, of treating the substrate with hydrogen to create the sacrificial $\mathrm{H}$ layers, can only find application for a few metal substrates, e.g., $\mathrm{Pd}$.)

(ii) The direct deposition of $\mathrm{M}_{\text {noble }}$ on $\mathrm{M}$ or $\mathrm{M} / \mathrm{C}$ nanoparticles, despite giving promising results especially for methanol and $\mathrm{CO}$ oxidation at $\mathrm{Pt}(\mathrm{Cu})$ electrodes, still suffers from rather low noble metal mass utilization. This is due to the penetration of $\mathrm{M}_{\text {noble }}$ into the $\mathrm{M}$ core, the need for use of rather large $\mathrm{M}$ precursor particles (thus increasing surface area) and, for $\mathrm{M} / \mathrm{C}$ particles, the simultaneous deposition of $\mathrm{M}_{\text {noble }}$ on $\mathrm{C}$. Ways to move forward with this variant will include the preparation of initially unsupported $\mathrm{M}_{\text {noble }}(\mathrm{M})$ nanoparticles with a thin outer shell and, possibly, a hollow interior too. This will require standardizing existing nanomaterials preparation routes and testing their products as electrocatalysts.

(iii) The direct deposition of $\mathrm{M}_{\text {noble }}$ on $\mathrm{M}$ bulk substrates is a straightforward approach that can find applications in alkaline and neutral media such as hydrogen production via water electrolysis and organic electrosynthesis. Future avenues should include the use of inexpensive substrates (e.g., stainless steel) and the screening of many organic reactions. 
In conclusion, the present review has shown that galvanic replacement has been established as a simple and cost-effective method for the production of catalysts for a number of important electrochemical applications.

Conflicts of Interest: The authors declare no conflict of interest.

\section{References}

1. Osakada, K. Transmetalation. In Current Methods in Inorganic Chemistry, Fundamentals of Molecular Catalysis; Kurosawa, H., Yamamoto, A., Eds.; Elsevier: Amsterdam, The Netherlands, 2003; Volume 3, pp. $233-291$.

2. Kunces, D. Chemical deposition of metallic films from aqueous solutions. In Electroless Plating: Fundamentals and Applications, 1st ed.; Mallory, G.O., Hajdu, J.B., Eds.; Noyes Publications/William Andrew Publishing, LLC: Norwich, NY, US, 1990; pp. 511-517.

3. Moon, G.D.; Ko, S.; Min, Y.; Zeng, J.; Xia, Y.; Jeong, U. Chemical transformations of nanostructured materials. Nano Today 2011, 6, 186-203. [CrossRef]

4. Bard, A.J.; Parsons, R.; Jordan, J. Standard Potentials in Aqueous Solution; Marcel Dekker, Inc.: New York, NY, USA; Basel, Switzerland, 1985.

5. Beverskog, B.; Puigdomenech, I. Revised pourbaix diagrams for chromium at $25-300{ }^{\circ}$ C. Corros. Sci. 1997, 39, 43-57. [CrossRef]

6. Brankovic, S.; Zangari, G. Electrochemical surface processes and opportunities for materials synthesis. In Electrochemical Engineering across Scales: From Molecules to Processes; Alkire, R.C., Bartlett, P.N., Lipkowski, J., Eds.; Wiley-VCH Verlag GmbH \& Co, KGaA: Weinheim, Germany, 2015; pp. 59-106.

7. Gokcen, D.; Yuan, Q.; Brankovic, S.R. Nucleation of Pt monolayers deposited via surface limited redox replacement reaction. J. Electrochem. Soc. 2014, 161, D3051-D3056. [CrossRef]

8. Dimitrov, N.; Vasilic, R.; Vasiljevic, N. A kinetic model for redox replacement of UPD layers. Electrochem. Solid State Lett. 2007, 10, D79-D83. [CrossRef]

9. Gokcen, D.; Bae, S.-E.; Brankovic, S.R. Kinetics of metal deposition via surface-limited redox replacement reaction. ECS Trans. 2011, 35, 11-22.

10. Gokcen, D.; Bae, S.-E.; Brankovic, S.R. Reaction kinetics of metal deposition via surface limited red-ox replacement of underpotentially deposited metal monolayers. Electrochim. Acta 2011, 56, 5545-5553. [CrossRef]

11. Bulut, E.; Wu, D.; Dole, N.; Kilic, H.; Brankovic, S.R. Reaction kinetics of metal deposition via surface limited redox replacement of underpotentially deposited monolayer studied by surface reflectivity and open circuit potential measurements. J. Electrochem. Soc. 2017, 164, D159-D168. [CrossRef]

12. Mkwizu, T.S.; Cukrowski, I. Physico-chemical modelling of adlayer phase formation via surface-limited reactions of copper in relation to sequential electrodeposition of multilayered platinum on crystalline gold. Electrochim. Acta 2014, 147, 432-441. [CrossRef]

13. Podlovchenko, B.I.; Gladysheva, T.D.; Filatov, A.Y.; Yashina, L.V. The use of galvanic displacement in synthesizing $\operatorname{Pt}(\mathrm{Cu})$ catalysts with the core-shell structure. Russ. J. Electrochem. 2010, 46, 1189-1197. [CrossRef]

14. Pletcher, D.; Walsh, F. Industrial Electrochemistry, 2nd ed.; Chapman and Hall: London, UK, 1990; pp. 498-502.

15. Cabrera, N.; Mott, N.F. Theory of the oxidation of metals. Rep. Prog. Phys. 1949, 12, 163-184. [CrossRef]

16. Werbicki, J.J., Jr. Practical electroless and immersion plating. Plating 1971, 58, 763-767.

17. Wingenfeld, P. Advanced technology for selective plating of connectors. Met. Finish. 1994, 92, 13-18.

18. Walsh, D.E.; Milad, G.; Gudeczauskas, D. Final finish: Printed circuit boards. Met. Finish. 2003, 101, $25-26$. [CrossRef]

19. Walsh, D.E.; Milad, G.; Gudeczauskas, D. Printed circuit boards: Final finish options. Prod. Finish. (Cincinnati) 2004, 68, 50-53. [CrossRef]

20. Couble, E.C.; Dutkewych, O.B.; Florio, S.M.; Marsh, M.V.; Staniunas, R.F. Immersion, non-electrolytic tin/lead plating process. Circuit World 1992, 19, 63-70. [CrossRef]

21. Milad, G.; Mayes, R. Electroless nickel/immersion gold finishes for application to surface mount technology: A regenerative approach. Met. Finish. 1998, 96, 44-46. [CrossRef]

22. Gudeczauskas, D.; Hashimoto, S.; Kiso, M. Gold plating. Print. Circuit Fabr. 1999, 22, 30-33. 
23. Blair, A. Silver plating. Plat. Surf. Finish. 2003, 90, 42-47.

24. Lashmore, D.S. Plating on aluminium: A review. Plat. Surf. Finish. 1985, 72, 36-39.

25. Pushpavanam, M.; Natarajan, S.R.; Sudha, S.; Vidhya, M. Decorative plating on aluminum. Met. Finish. 1993, 91, 16-20.

26. Stoyanova, E.; Stoychev, D. Electrochemical aspects of the immersion treatment of aluminium. J. Appl. Electrochem. 1997, 27, 685-690. [CrossRef]

27. Rossi, S.; Fedrizzi, L.; Deflorian, F. Characterization of commercial metallic coatings for corrosion protection of P/M parts. Int. J. Powder Metall. 2004, 40, 33-40.

28. Biswas, A.K.; Davenport, W.G. Extractive Metallurgy of Copper, 2nd ed.; Pergamon Press Ltd.: Oxford, UK, 1980; p. 272.

29. Scott, D.A. Copper and Bronze in Art: Corrosion, Colorants, Conservation; Getty Publications: Los Angeles, CA, USA, 2002; p. 17.

30. Petala, M.; Tsiridis, V.; Mintsouli, I.; Pliatsikas, N.; Spanos, T.; Rebeyre, P.; Darakas, E.; Patsalas, P.; Vourlias, G.; Kostoglou, M.; et al. Silver deposition on stainless steel container surfaces in contact with disinfectant silver aqueous solutions. Appl. Surf. Sci. 2017, 396, 1067-1075. [CrossRef]

31. Dimitrov, N. Recent advances in the growth of metals, alloys, and multilayers by surface limited redox replacement (SLRR) based approaches. Electrochim. Acta 2016, 209, 599-622. [CrossRef]

32. Herrero, E.; Buller, L.J.; Abruña, H.D. Underpotential deposition at single crystal surfaces of Au, Pt, Ag and other materials. Chem. Rev. 2001, 101, 1897-1930. [CrossRef] [PubMed]

33. Gregory, B.W.; Wayne Suggs, D.; Stickney, J.L. Conditions for the deposition of CdTe by electrochemical atomic layer epitaxy. J. Electrochem. Soc. 1991, 138, 1279-1284. [CrossRef]

34. Gregory, B.W.; Stickney, J.L. Electrochemical atomic layer epitaxy (ECALE). J. Electroanal. Chem. 1991, 300, 543-561. [CrossRef]

35. Villegas, I.; Stickney, J.L. Preliminary studies of GaAs deposition on Au(100), (110), and (111) surfaces by electrochemical atomic layer epitaxy. J. Electrochem. Soc. 1992, 139, 686-694. [CrossRef]

36. Suggs, D.W.; Villegas, I.; Gregory, B.W.; Stickney, J.L. Formation of compound semiconductors by electrochemical atomic layer epitaxy. J. Vac. Sci. Technol. A 1992, 10, 886-891. [CrossRef]

37. Brankovic, S.R.; Wang, J.X.; Adžić, R.R. Metal monolayer deposition by replacement of metal adlayers on electrode surfaces. Surf. Sci. 2001, 474, L173-L179. [CrossRef]

38. Mrozek, M.F.; Xie, Y.; Weaver, M.J. Surface-enhanced Raman scattering on uniform platinum-group overlayers: Preparation by redox replacement of underpotential-deposited metals on gold. Anal. Chem. 2001, 73, 5953-5960. [CrossRef] [PubMed]

39. Vasilic, R.; Dimitrov, N. Epitaxial growth by monolayer-restricted galvanic displacement. Electrochem. Solid State Lett. 2005, 8, C173-C176. [CrossRef]

40. Vasilic, R.; Viyannalage, L.T.; Dimitrov, N. Epitaxial growth of Ag on Au(111) by galvanic displacement of $\mathrm{Pb}$ and $\mathrm{Tl}$ monolayers. J. Electrochem. Soc. 2006, 153, C648-C655. [CrossRef]

41. Viyannalage, L.T.; Vasilic, R.; Dimitrov, N. Epitaxial growth of $\mathrm{Cu}$ on $\mathrm{Au}(111)$ and $\mathrm{Ag}(111)$ by surface limited redox replacement-An electrochemical and STM study. J. Phys. Chem. C 2007, 111, 4036-4041. [CrossRef]

42. Fayette, M.; Liu, Y.; Bertrand, D.; Nutariya, J.; Vasiljevic, N.; Dimitrov, N. From Au to Pt via surface limited redox replacement of $\mathrm{Pb}$ UPD in one-cell configuration. Langmuir 2011, 27, 5650-5658. [CrossRef] [PubMed]

43. Bromberg, L.; Fayette, M.; Martens, B.; Luo, Z.P.; Wang, Y.; Xu, D.; Zhang, J.; Fang, J.; Dimitrov, N. Catalytic performance comparison of shape-dependent nanocrystals and oriented ultrathin films of pt4cu alloy in the formic acid oxidation process. Electrocatalysis 2013, 4, 24-36. [CrossRef]

44. Nutariya, J.; Fayette, M.; Dimitrov, N.; Vasiljevic, N. Growth of Pt by surface limited redox replacement of underpotentially deposited hydrogen. Electrochim. Acta 2013, 112, 813-823. [CrossRef]

45. Ambrozik, S.; Rawlings, B.; Vasiljevic, N.; Dimitrov, N. Metal deposition via electroless surface limited redox replacement. Electrochem. Commun. 2014, 44, 19-22. [CrossRef]

46. Ambrozik, S.; Dimitrov, N. The deposition of Pt via electroless surface limited redox replacement. Electrochim. Acta 2015, 169, 248-255. [CrossRef]

47. Kim, Y.-G.; Kim, J.Y.; Vairavapandian, D.; Stickney, J.L. Platinum nanofilm formation by EC-ALE via redox replacement of UPD copper: Studies using in-situ scanning tunneling microscopy. J. Phys. Chem. B 2006, 110, 17998-18006. [CrossRef] [PubMed] 
48. Kim, J.Y.; Kim, Y.-G.; Stickney, J.L. Studies of $\mathrm{Cu}$ atomic layer replacement, formed by underpotential deposits, to form Pt nanofilms using Electrochemical Atomic Layer Epitaxy (EC-ALE). ECS Trans. 2006, 1, 41-48.

49. Hossain, M.A.; Cummins, K.D.; Park, Y.-S.; Soriaga, M.P.; Stickney, J.L. Layer-by-layer deposition of Pd on $\mathrm{Pt}(111)$ electrode: An electron spectroscopy-electrochemistry study. Electrocatalysis 2012, 3, $183-191$. [CrossRef]

50. Jayaraju, N.; Vairavapandian, D.; Kim, Y.G.; Banga, D.; Stickney, J.L. Electrochemical atomic layer deposition (E-ALD) of Pt nanofilms using SLRR cycles. J. Electrochem. Soc. 2012, 159, D616-D622. [CrossRef]

51. Sheridan, L.B.; Gebregziabiher, D.K.; Stickney, J.L.; Robinson, D.B. Formation of palladium nanofilms using electrochemical atomic layer deposition (E-ALD) with chloride complexation. Langmuir 2013, 29, 1592-1600. [CrossRef] [PubMed]

52. Jayaraju, N.; Banga, D.; Thambidurai, C.; Liang, X.; Kim, Y.-G.; Stickney, J.L. PtRu nanofilm formation by electrochemical atomic layer deposition (E-ALD). Langmuir 2014, 30, 3254-3263. [CrossRef] [PubMed]

53. Cappillino, P.J.; Sugar, J.D.; El Gabaly, F.; Cai, T.Y.; Liu, Z.; Stickney, J.L.; Robinson, D.B. Atomic-layer electroless deposition: A scalable approach to surface-modified metal powders. Langmuir 2014, 30, 4820-4829. [CrossRef] [PubMed]

54. Xia, X.; Wang, Y.; Ruditskiy, A.; Xia, Y. 25th anniversary article: Galvanic replacement: A simple and versatile route to hollow nanostructures with tunable and well-controlled properties. Adv. Mater. 2013, 25, 6313-6332. [CrossRef] [PubMed]

55. Zhao, M.; Crooks, R.M. Intradendrimer exchange of metal nanoparticles. Chem. Mater. 1999, 11, 3379-3385. [CrossRef]

56. Park, J.-I.; Cheon, J. Synthesis of "solid solution" and "core-shell" type cobalt-platinum magnetic nanoparticles via transmetalation reactions. J. Am. Chem. Soc. 2001, 123, 5743-5746. [CrossRef] [PubMed]

57. Shon, Y.-S.; Dawson, G.B.; Porter, M.; Murray, R.W. Monolayer-protected bimetal cluster synthesis by core metal galvanic exchange reaction. Langmuir 2002, 18, 3880-3885. [CrossRef]

58. Sun, Y.; Mayers, B.T.; Xia, Y. Template-engaged replacement reaction: A one-step approach to the large-scale synthesis of metal nanostructures with hollow interiors. Nano Lett. 2002, 2, 481-485. [CrossRef]

59. Chen, J.; Glaus, C.; Laforest, R.; Zhang, Q.; Yang, M.; Gidding, M.; Welch, M.J.; Xia, Y. Gold nanocages as photothermal transducers for cancer treatment. Small 2010, 6, 811-817. [CrossRef] [PubMed]

60. Wang, Y.; Liu, Y.; Luehmann, H.; Xia, X.; Wan, D.; Cutler, C.; Xia, Y. Radioluminescent gold nanocages with controlled radioactivity for real-time in vivo imaging. Nano Lett. 2013, 13, 581-585. [CrossRef] [PubMed]

61. Zhou, X.; Gan, Y.; Du, J.; Tian, D.; Zhang, R.; Yang, C.; Dai, Z. A review of hollow Pt-based nanocatalysts applied in proton exchange membrane fuel cells. J. Power Sources 2013, 232, 310-322. [CrossRef]

62. Liu, B.; Liao, S.; Liang, Z. Core-shell structure: The best way to achieve low-Pt fuel cell electrocatalysts. Prog. Chem. 2011, 23, 852-859.

63. Lai, X.; Halpert, J.E.; Wang, D. Recent advances in micro-/nano-structured hollow spheres for energy applications: From simple to complex systems. Energy Environ. Sci. 2012, 5, 5604-5618. [CrossRef]

64. Adzic, R.R.; Zhang, J.; Sasaki, K.; Vukmirovic, M.B.; Shao, M.; Wang, J.X.; Nilekar, A.U.; Mavrikakis, M.; Valerio, J.A.; Uribe, F. Platinum monolayer fuel cell electrocatalysts. Top. Catal. 2007, 46, 249-262. [CrossRef]

65. Sasaki, K.; Vukmirovic, M.B.; Wang, J.X.; Adzic, R.R. Platinum monolayer electrocatalysts: Improving structure and activity. In Fuel Cell Science: Theory, Fundamentals, and Biocatalysis; Wieckowski, A., Nørskov, J.K., Eds.; Wiley: Hoboken, NJ, USA, 2010; pp. 215-236.

66. Bliznakov, S.; Vukmirovic, M.; Adzic, R. Electrochemical atomic-level controlled syntheses of electrocatalysts for the oxygen reduction reaction. RSC Catal. Ser. 2015, 22, 144-166.

67. Papadimitriou, S.; Armyanov, S.; Valova, E.; Hubin, A.; Steenhaut, O.; Pavlidou, E.; Kokkinidis, G.; Sotiropoulos, S. Methanol oxidation at $\mathrm{Pt}-\mathrm{Cu}, \mathrm{Pt}-\mathrm{Ni}$, and $\mathrm{Pt}-\mathrm{Co}$ electrode coatings prepared by a galvanic replacement process. J. Phys. Chem. C 2010, 114, 5217-5223. [CrossRef]

68. Geboes, B.; Mintsouli, I.; Wouters, B.; Georgieva, J.; Kakaroglou, A.; Sotiropoulos, S.; Valova, E.; Armyanov, S.; Hubin, A.; Breugelmans, T. Surface and electrochemical characterisation of a $\mathrm{Pt}-\mathrm{Cu} / \mathrm{C}$ nano-structured electrocatalyst, prepared by galvanic displacement. Appl. Catal. B 2014, 150-151, 249-256. [CrossRef] 
69. Kuznetsov, V.V.; Podlovchenko, B.I.; Kavyrshina, K.V.; Maksimov, Yu.M. Oxidation of methanol on Pt(Mo) electrodes obtained using galvanic displacement method. Russ. J. Electrochem. 2010, 46, 1353-1359. [CrossRef]

70. Podlovchenko, B.I.; Krivchenko, V.A.; Maksimov, Y.M.; Gladysheva, T.D.; Yashina, L.V.; Evlashin, S.A.; Pilevsky, A.A. Specific features of the formation of $\mathrm{Pt}(\mathrm{Cu})$ catalysts by galvanic displacement with carbon nanowalls used as support. Electrochim. Acta 2012, 76, 137-144. [CrossRef]

71. Vázquez-Gómez, L.; Cattarin, S.; Guerriero, P.; Musiani, M. Hydrogen evolution on porous Ni cathodes modified by spontaneous deposition of Ru or Ir. Electrochim. Acta 2008, 53, 8310-8318. [CrossRef]

72. Verlato, E.; Cattarin, S.; Comisso, N.; Gambirasi, A.; Musiani, M.; Vázquez-Gómez, L. Preparation of Pd-modified Ni foam electrodes and their use as anodes for the oxidation of alcohols in basic media. Electrocatalysis 2012, 3, 48-58. [CrossRef]

73. Kokkinidis, G.; Papoutsis, A.; Stoychev, D.; Milchev, A. Electroless deposition of Pt on Ti-Catalytic activity for the hydrogen evolution reaction. J. Electroanal. Chem. 2000, 486, 48-55. [CrossRef]

74. Kokkinidis, G.; Stoychev, D.; Lazarov, V.; Papoutsis, A.; Milchev, A. Electroless deposition of Pt on Ti: Part II. Catalytic activity for oxygen reduction. J. Electroanal. Chem. 2001, 511, 20-30. [CrossRef]

75. Van Brussel, M.; Kokkinidis, G.; Vandendael, I.; Buess-Herman, C. High performance gold-supported platinum electrocatalyst for oxygen reduction. Electrochem. Commun. 2002, 4, 808-813. [CrossRef]

76. Van Brussel, M.; Kokkinidis, G.; Hubin, A.; Buess-Herman, C. Oxygen reduction at platinum modified gold electrodes. Electrochim. Acta 2003, 48, 3909-3919. [CrossRef]

77. Brankovic, S.R.; McBreen, J.; Adžić, R.R. Spontaneous deposition of Pt on the Ru(0001) surface. J. Electroanal. Chem. 2001, 503, 99-104. [CrossRef]

78. Brankovic, S.R.; Wang, J.X.; Adžić, R.R. Pt submonolayers on Ru nanoparticles. A novel low Pt loading, high CO tolerance fuel cell electrocatalyst. Electrochem. Solid State Lett. 2001, 4, A217-A220. [CrossRef]

79. Sasaki, K.; Mo, Y.; Wang, J.X.; Balasubramanian, M.; Uribe, F.; McBreen, J.; Adzic, R.R. Pt submonolayers on metal nanoparticles-Novel electrocatalysts for $\mathrm{H}_{2}$ oxidation and $\mathrm{O}_{2}$ reduction. Electrochim. Acta 2003, 48, 3841-3849. [CrossRef]

80. Sasaki, K.; Wang, J.X.; Balasubramanian, M.; McBreen, J.; Uribe, F.; Adzic, R.R. Ultra-low platinum content fuel cell anode electrocatalyst with a long-term performance stability. Electrochim. Acta 2004, 49, 3873-3877. [CrossRef]

81. Zhang, J.; Vukmirovic, M.B.; Xu, Y.; Mavrikakis, M.; Adzic, R.R. Controlling the catalytic activity of platinum-monolayer electrocatalysts for oxygen reduction with different substrates. Angew. Chem. Int. Ed. 2005, 44, 2132-2135. [CrossRef] [PubMed]

82. Zhang, J.; Vukmirovic, M.B.; Sasaki, K.; Nilekar, A.U.; Mavrikakis, M.; Adzic, R.R. Mixed-metal Pt monolayer electrocatalysts for enhanced oxygen reduction kinetics. J. Am. Chem. Soc. 2005, 127, 12480-12481. [CrossRef] [PubMed]

83. Zhang, J.; Lima, F.H.B.; Shao, M.H.; Sasaki, K.; Wang, J.X.; Hanson, J.; Adzic, R.R. Platinum monolayer on nonnoble metal-noble metal core-shell nanoparticle electrocatalysts for $\mathrm{O}_{2}$ reduction. J. Phys. Chem. B 2005, 109, 22701-22704. [CrossRef] [PubMed]

84. Sasaki, K.; Zhang, J.; Wang, J.; Uribe, F.; Adzic, R. Platinum submonolayer-monolayer electrocatalysts: An electrochemical and X-ray absorption spectroscopy study. Res. Chem. Intermed. 2006, 32, 543-559. [CrossRef]

85. Zhang, J.; Shao, M.H.; Sasaki, K.; Vukmirovic, M.B.; Uribe, F.; Adzic, R.R. Platinum and mixed platinum-metal monolayer fuel cell electrocatalysts: Design, activity and long-term performance stability. ECS Trans. 2006, 3, 31-36.

86. Vukmirovic, M.B.; Zhang, J.; Sasaki, K.; Nilekar, A.U.; Uribe, F.; Mavrikakis, M.; Adzic, R.R. Platinum monolayer electrocatalysts for oxygen reduction. Electrochim. Acta 2007, 52, 2257-2263. [CrossRef]

87. Nilekar, A.U.; Xu, Y.; Zhang, J.; Vukmirovic, M.B.; Sasaki, K.; Adzic, R.R.; Mavrikakis, M. Bimetallic and ternary alloys for improved oxygen reduction catalysis. Top. Catal. 2007, 46, 276-284. [CrossRef]

88. Xu, Y.; Shao, M.; Mavrikakis, M.; Adzic, R.R. Recent Developments in the electrocatalysis of the $\mathrm{O}_{2}$ reduction reaction. In Fuel Cell Catalysis: A Surface Science Approach; Koper, M.T.M., Ed.; Wiley: Hoboken, NJ, USA, 2009; pp. 271-315.

89. Ball, S.; Burton, S.L.; Fisher, J.; O’Malley, R.; Tessier, B.; Theobald, B.R.C.; Thompsett, D.; Zhou, W.P.; Su, D.; $\mathrm{Zhu}, \mathrm{Y}$; et al. Structure and activity of novel $\mathrm{Pt}$ core-shell catalysts for the oxygen reduction reaction. ECS Trans. 2009, 25, 1023-1036. 
90. Sasaki, K.; Wang, J.X.; Naohara, H.; Marinkovic, N.; More, K.; Inada, H.; Adzic, R.R. Recent advances in platinum monolayer electrocatalysts for oxygen reduction reaction: Scale-up synthesis, structure and activity of Pt shells on Pd cores. Electrochim. Acta 2010, 55, 2645-2652. [CrossRef]

91. Sasaki, K.; Naohara, H.; Cai, Y.; Choi, Y.M.; Liu, P.; Vukmirovic, M.B.; Wang, J.X.; Adzic, R.R. Core-protected platinum monolayer shell high-stability electrocatalysts for fuel-cell cathodes. Angew. Chem. Int. Ed. 2010, 49, 8602-8607. [CrossRef] [PubMed]

92. Cai, Y.; Adzic, R.R. Platinum monolayer electrocatalysts for the oxygen reduction reaction: Improvements induced by surface and subsurface modifications of cores. Adv. Phys. Chem. 2011, 2011, 530397. [CrossRef]

93. Adzic, R.R. Platinum monolayer electrocatalysts: Tunable activity, stability, and self-healing properties. Electrocatalysis 2012, 3, 163-169. [CrossRef]

94. Li, M.; Liu, P.; Adzic, R.R. Platinum monolayer electrocatalysts for anodic oxidation of alcohols. J. Phys. Chem. Lett. 2012, 3, 3480-3485. [CrossRef] [PubMed]

95. Li, M.; Adzic, R.R. Low-platinum-content electrocatalysts for methanol and ethanol electrooxidation. In Electrocatalysis in Fuel Cells; Lecture Notes in Energy; Springer: London, UK, 2013.

96. Kuttiyiel, K.A.; Choi, Y.M.; Sasaki, K.; Su, D.; Hwang, S.-M.; Yim, S.-D.; Yang, T.-H.; Park, G.-G.; Adzic, R.R. Tuning electrocatalytic activity of Pt monolayer shell by bimetallic $\mathrm{Ir}-\mathrm{M}(\mathrm{M}=\mathrm{Fe}, \mathrm{Co}, \mathrm{Ni}$ or $\mathrm{Cu})$ cores for the oxygen reduction reaction. Nano Energy 2016, 29, 261-267. [CrossRef]

97. Sasaki, K.; Marinkovic, N.; Isaacs, H.S.; Adzic, R.R. Synchrotron-based in situ characterization of carbon-supported platinum and platinum monolayer electrocatalysts. ACS Catal. 2016, 6, 69-76. [CrossRef]

98. Khatee, S.; Guerreo, S.; Su, D.; Darling, R.M.; Protsailo, L.V.; Shao, M. Fuel cell performance of palladium-platinum core-shell electrocatalysts synthesized in gram-scale batches. J. Electrochem. Soc. 2016, 163, F708-F713. [CrossRef]

99. Zhu, S.; Yue, J.; Qin, X.; Wei, Z.; Liang, Z.; Adzic, R.R.; Brankovic, S.R.; Du, Z.; Shao, M. The role of citric acid in perfecting platinum monolayer on palladium nanoparticles during the surface limited redox replacement reaction. J. Electrochem. Soc. 2016, 163, D3040-D3046. [CrossRef]

100. Papadimitriou, S.; Tegou, A.; Pavlidou, E.; Kokkinidis, G.; Sotiropoulos, S. Methanol oxidation at platinized lead coatings prepared by a two-step electrodeposition-electroless deposition process on glassy carbon and platinum substrates. Electrochim. Acta 2007, 52, 6254-6260. [CrossRef]

101. Tegou, A.; Papadimitriou, S.; Pavlidou, E.; Kokkinidis, G.; Sotiropoulos, S. Oxygen reduction at platinum- and gold-coated copper deposits on glassy carbon substrates. J. Electroanal. Chem. 2007, 608, 67-77. [CrossRef]

102. Papadimitriou, S.; Tegou, A.; Pavlidou, E.; Armyanov, S.; Valova, E.; Kokkinidis, G.; Sotiropoulos, S. Preparation and characterisation of platinum- and gold-coated copper, iron, cobalt and nickel deposits on glassy carbon substrates. Electrochim. Acta 2008, 53, 6559-6567. [CrossRef]

103. Tegou, A.; Papadimitriou, S.; Armyanov, S.; Valova, E.; Kokkinidis, G.; Sotiropoulos, S. Oxygen reduction at platinum- and gold-coated iron, cobalt, nickel and lead deposits on glassy carbon substrates. J. Electroanal. Chem. 2008, 623, 187-196. [CrossRef]

104. Tegou, A.; Armyanov, S.; Valova, E.; Steenhaut, O.; Hubin, A.; Kokkinidis, G.; Sotiropoulos, S. Mixed platinum-gold electrocatalysts for borohydride oxidation prepared by the galvanic replacement of nickel deposits. J. Electroanal. Chem. 2009, 634, 104-110. [CrossRef]

105. Tegou, A.; Papadimitriou, S.; Kokkinidis, G.; Sotiropoulos, S. A rotating disc electrode study of oxygen reduction at platinised nickel and cobalt coatings. J. Solid State Electrochem. 2010, 14, 175-184. [CrossRef]

106. Tegou, A.; Papadimitriou, S.; Mintsouli, I.; Armyanov, S.; Valova, E.; Kokkinidis, G.; Sotiropoulos, S. Rotating disc electrode studies of borohydride oxidation at Pt and bimetallic Pt-Ni and Pt-Co electrodes. Catal. Today 2011, 170, 126-133. [CrossRef]

107. Mintsouli, I.; Georgieva, J.; Valova, E.; Armyanov, S.; Kakaroglou, A.; Hubin, A.; Steenhaut, O.; Dille, J.; Papaderakis, A.; Kokkinidis, G.; et al. Pt-Ni carbon-supported catalysts for methanol oxidation prepared by Ni electroless deposition and its galvanic replacement by Pt. J. Solid State Electrochem. 2013, 17, $435-443$. [CrossRef]

108. Mintsouli, I.; Georgieva, J.; Armyanov, S.; Valova, E.; Avdeev, G.; Hubin, A.; Steenhaut, O.; Dille, J.; Tsiplakides, D.; Balomenou, S.; et al. Pt-Cu electrocatalysts for methanol oxidation prepared by partial galvanic replacement of $\mathrm{Cu}$ /carbon powder precursors. Appl. Catal. B 2013, 136-137, 160-167. [CrossRef] 
109. Papaderakis, A.; Pliatsikas, N.; Prochaska, C.; Papazisi, K.M.; Balomenou, S.P.; Tsiplakides, D.; Patsalas, P.; Sotiropoulos, S. Ternary Pt-Ru-Ni catalytic layers for methanol electrooxidation prepared by electrodeposition and galvanic replacement. Front. Chem. 2014, 2, 29. [CrossRef] [PubMed]

110. Georgieva, J.; Valova, E.; Mintsouli, I.; Sotiropoulos, S.; Armyanov, S.; Kakaroglou, A.; Hubin, A.; Steenhaut, O.; Dille, J. Carbon-supported $\mathrm{Pt}(\mathrm{Cu})$ electrocatalysts for methanol oxidation prepared by $\mathrm{Cu}$ electroless deposition and its galvanic replacement by Pt. J. Appl. Electrochem. 2014, 44, 215-224. [CrossRef]

111. Georgieva, J.; Sotiropoulos, S.; Valova, E.; Armyanov, S.; Karanasios, N. Methanol oxidation and photo-oxidation at $\mathrm{Pt} / \mathrm{WO}_{3}$ electrocatalysts on graphite substrates. J. Electroanal. Chem. 2014, 727, 135-140. [CrossRef]

112. Georgieva, J.; Valova, E.; Mintsouli, I.; Sotiropoulos, S.; Tatchev, D.; Armyanov, S.; Hubin, A.; Dille, J.; Hoell, A.; Raghuwanshi, V.; et al. $\mathrm{Pt}(\mathrm{Ni})$ electrocatalysts for methanol oxidation prepared by galvanic replacement on $\mathrm{TiO}_{2}$ and $\mathrm{TiO}_{2} / C$ powder supports. J. Electroanal. Chem. 2015, 754, 65-74. [CrossRef]

113. Papaderakis, A.; Pliatsikas, N.; Prochaska, C.; Vourlias, G.; Patsalas, P.; Tsiplakides, D.; Balomenou, S.; Sotiropoulos, S. Oxygen evolution at $\mathrm{IrO}_{2}$ shell-Ir-Ni core electrodes prepared by galvanic replacement. J. Phys. Chem. C 2016, 120, 19995-20005. [CrossRef]

114. Tveritinova, E.A.; Maksimov, Y.M.; Zhitnev, Y.N.; Podlovchenko, B.I.; Lunin, V.V. Use of galvanic displacement in the synthesis of a $\operatorname{Pd}(\mathrm{Cu})$ hydrodechlorination catalyst. Mendeleev Commun. 2010, 20, 10-11. [CrossRef]

115. Zhumaev, U.E.; Maksimov, Y.M.; Podlovchenko, B.I. Galvanic replacement of copper adatoms from a Pt/Pt electrode surface in $\mathrm{H}_{2} \mathrm{PtCl}_{6}$ solutions. Mendeleev Commun. 2011, 21, 29-30. [CrossRef]

116. Podlovchenko, B.I.; Zhumaev, U.E.; Maksimov, Y.M. Galvanic displacement of copper adatoms on platinum in $\mathrm{PtCl}_{4}{ }^{2-}$ solutions. J. Electroanal. Chem. 2011, 651, 30-37. [CrossRef]

117. Podlovchenko, B.I.; Gladysheva, T.D.; Filatov, A.Y.; Yashina, L.V. Peculiarities of the Pt(Cu)/C catalyst formation by galvanic displacement of copper in $\mathrm{H}_{2} \mathrm{PtCl}_{4}$ solutions. Russ. J. Electrochem. 2012, 48, 173-180. [CrossRef]

118. Kuznetsov, V.V.; Kavyrshina, K.V.; Podlovchenko, B.I. Formation and electrocatalytic properties of Pd deposits on Mo obtained by galvanic displacement. Russ. J. Electrochem. 2012, 48, 467-473. [CrossRef]

119. Podlovchenko, B.I.; Gladysheva, T.D.; Krivchenko, V.A.; Maksimov, Y.M.; Filatov, A.Y.; Yashina, L.V. Effect of copper deposit morphology on the characteristics of a $\mathrm{Pt}(\mathrm{Cu}) / \mathrm{C}$-catalyst obtained by galvanic displacement. Mendeleev Commun. 2012, 22, 203-205. [CrossRef]

120. Kuznetsov, V.V.; Kavyrshina, K.V.; Podlovchenko, B.I. Carbon monoxide adsorption and electrooxidation at a Pd(Mo) electrode prepared by galvanic displacement. Mendeleev Commun. 2012, 22, 206-207. [CrossRef]

121. Podlovchenko, B.I.; Maksimov, Y.M. Open-circuit potentials established on platinum and gold electrodes in $\mathrm{PtCl}^{2-}{ }_{4}$ solutions after the displacement of copper adatoms. Mendeleev Commun. 2013, 23, 157-159. [CrossRef]

122. Podlovchenko, B.I.; Maksimov, Y.M.; Maslakov, K.I. Electrocatalytic properties of Au electrodes decorated with Pt submonolayers by galvanic displacement of copper adatoms. Electrochim. Acta 2014, 130, 351-360. [CrossRef]

123. Gladysheva, T.D.; Filatov, A.Y.; Podlovchenko, B.I. Modification of platinum electrodeposits with an ultralow amount of palladium through the galvanic displacement of hydrogen and copper adatoms. Mendeleev Commun. 2015, 25, 56-58. [CrossRef]

124. Podlovchenko, B.I.; Maksimov, Y.M.; Evlashin, S.A.; Gladysheva, T.D.; Maslakov, K.I.; Krivchenko, V.A. The use of galvanic displacement in synthesizing $\mathrm{Pt}^{0}(\mathrm{Bi}) / \mathrm{CNW}$ catalysts highly active in electrooxidation of formic acid. J. Electroanal. Chem. 2015, 743, 93-98. [CrossRef]

125. Podlovchenko, B.I.; Gladysheva, T.D.; Filatov, A.Y. Galvanic-displacement modification of Pd deposits with ultralow amounts of platinum and the electrocatalytic properties of the mixed catalyst. Mendeleev Commun. 2015, 25, 293-295. [CrossRef]

126. Podlovchenko, B.I.; Maksimov, Y.M. Peculiarities in the electrocatalytic behavior of ultralow platinum deposits on gold synthesized by galvanic displacement. J. Electroanal. Chem. 2015, 756, 140-146. [CrossRef]

127. Podlovchenko, B.I.; Kuznetsov, V.V.; Batalov, R.S. Palladium catalyst modified with molybdenum bronze as a possible alternative to platinum in the methanol oxidation reaction. J. Solid State Electr. 2016, 20, 589-595. [CrossRef] 
128. Kuznetsov, V.V.; Batalov, R.S.; Podlovchenko, B.I. $n \mathrm{Pd}^{0} \cdot\left(\mathrm{H}_{x-2 n} \mathrm{MoO}_{3}\right)$ composites as catalysts of methanol and formic acid electrooxidation. Russ. J. Electrochem. 2016, 52, 408-419. [CrossRef]

129. Vázquez-Gómez, L.; Cattarin, S.; Gerbasi, R.; Guerriero, P.; Musiani, M. Activation of porous Ni cathodes towards hydrogen evolution by electrodeposition of Ir nuclei. J. Appl. Electrochem. 2009, 39, 2165-2172. [CrossRef]

130. Verlato, E.; Cattarin, S.; Comisso, N.; Guerriero, P.; Musiani, M.; Vázquez-Gómez, L. Preparation of catalytic anodes for methanol oxidation by spontaneous deposition of Pd onto porous Ni or porous Co. Electrochem. Commun. 2010, 12, 1120-1123. [CrossRef]

131. Vázquez-Gómez, L.; Cattarin, S.; Comisso, N.; Guerriero, P.; Musiani, M.; Verlato, E. Spontaneous deposition of Pd onto Fe-Cr-Al alloys. Electrochim. Acta 2012, 68, 114-122. [CrossRef]

132. Fiameni, S.; Herraiz-Cardona, I.; Musiani, M.; Pérez-Herranz, V.; Vázquez-Gómez, L.; Verlato, E. The HER in alkaline media on Pt-modified three-dimensional Ni cathodes. Int. J. Hydrogen Energy 2012, 37, 10507-10516. [CrossRef]

133. Cimino, S.; Gerbasi, R.; Lisi, L.; Mancino, G.; Musiani, M.; Vázquez-Gómez, L.; Verlato, E. Oxidation of CO and $\mathrm{CH}_{4}$ on Pd-FeCr alloy foam catalysts prepared by spontaneous deposition. Chem. Eng. J. 2013, 230, 422-431. [CrossRef]

134. Verlato, E.; Cattarin, S.; Comisso, N.; Mattarozzi, L.; Musiani, M.; Vázquez-Gómez, L. Reduction of nitrate ions at Rh-modified Ni foam electrodes. Electrocatalysis 2013, 4, 203-211. [CrossRef]

135. Verlato, E.; Cattarin, S.; Comisso, N.; Mattarozzi, L.; Musiani, M.; Vázquez-Gómez, L. Electrochemical Impedance Spectroscopy study of the preparation of electrocatalysts through galvanic displacement reactions. J. Electroanal. Chem. 2015, 737, 100-107. [CrossRef]

136. Musiani, M.; Cattarin, S.; Cimino, S.; Comisso, N.; Mattarozzi, L.; Vázquez-Gómez, L.; Verlato, E. Preparation of 3D electrocatalysts and catalysts for gas-phase reactions, through electrodeposition or galvanic displacement. J. Appl. Electrochem. 2015, 45, 715-725. [CrossRef]

137. Verlato, E.; He, W.; Amrane, A.; Barison, S.; Floner, D.; Fourcade, F.; Geneste, F.; Musiani, M.; Seraglia, R. Preparation of silver-modified nickel foams by galvanic displacement and their use as cathodes for the reductive dechlorination of herbicides. ChemElectroChem 2016. [CrossRef]

138. Comisso, N.; Cattarin, S.; Guerriero, P.; Mattarozzi, L.; Musiani, M.; Vázquez-Gómez, L.; Verlato, E. Study of $\mathrm{Cu}, \mathrm{Cu}-\mathrm{Ni}$ and $\mathrm{Rh}$-modified $\mathrm{Cu}$ porous layers as electrode materials for the electroanalysis of nitrate and nitrite ions. J. Solid State Electr. 2016, 20, 1139-1148. [CrossRef]

139. Bianchi, I.; Guerrini, E.; Trasatti, S. Electrocatalytic activation of Ni for $\mathrm{H}_{2}$ evolution by spontaneous deposition of Ru. Chem. Phys. 2005, 319, 192-199. [CrossRef]

140. Duca, M.; Guerrini, E.; Colombo, A.; Trasatti, S. Activation of nickel for hydrogen evolution by spontaneous deposition of iridium. Electrocatalysis 2013, 4, 338-345. [CrossRef]

141. Oh, M.H.; Yu, T.; Yu, S.-H.; Lim, B.; Ko, K.-T.; Willinger, M.-G.; Seo, D.-H.; Kim, B.H.; Cho, M.G.; Park, J.-H.; et al. Galvanic replacement reactions in metal oxide nanocrystals. Science 2013, 340, 964-968. [CrossRef] [PubMed]

142. Comisso, N.; Cattarin, S.; Guerriero, P.; Mattarozzi, L.; Musiani, M.; Verlato, E. Conversion of porous $\mathrm{PbO}_{2}$ layers through galvanic displacement reaction with $\mathrm{Mn}^{2+}$ ions. Electrochem. Commun. 2016, 73, 59-62. [CrossRef]

143. Ruban, A.; Hammer, B.; Stoltze, P.; Skriver, H.L.; Nørskov, J.K. Surface electronic structure and reactivity of transition and noble metals. J. Mol. Catal. A 1997, 115, 421-429. [CrossRef]

144. Kitchin, J.R.; Nørskov, J.K.; Barteau, M.A.; Chen, J.G. Modification of the surface electronic and chemical properties of $\mathrm{Pt}(111)$ by subsurface 3d transition metals. J. Chem. Phys. 2004, 120, 10240-10246. [CrossRef] [PubMed]

145. Bae, S.-E.; Gokcen, D.; Liu, P.; Mohammadi, P.; Brankovic, S.R. Size effects in monolayer catalysis-model study: Pt submonolayers on Au(111). Electrocatalysis 2012, 3, 203-210. [CrossRef]

146. Loukrakpam, R.; Yuan, Q.; Petkov, V.; Gan, L.; Rudi, S.; Yang, R.; Huang, Y.; Brankovic, S.R.; Strasser, P. Efficient $\mathrm{C}-\mathrm{C}$ bond splitting on Pt monolayer and sub-monolayer catalysts during ethanol electro-oxidation: Pt layer strain and morphology effects. Phys. Chem. Chem. Phys. 2014, 16, 18866-18876. [CrossRef] [PubMed]

147. Grabow, L.C.; Yuan, Q.; Doan, H.A.; Brankovic, S.R. Novel 2D RuPt core-edge nanocluster catalyst for CO electro-oxidation. Surf. Sci. 2015, 640, 50-58. [CrossRef] 
148. Kühl, S.; Strasser, P. Oxygen electrocatalysis on dealloyed Pt nanocatalysts. Top. Catal. 2016, 59, $1628-1637$. [CrossRef]

149. Kibler, L.A. Dependence of electrocatalytic activity on film thickness for the hydrogen evolution reaction of Pd overlayers on Au(111). Electrochim. Acta 2008, 53, 6824-6828. [CrossRef]

150. Wang, X.; Wang, H.; Wang, R.; Wang, Q.; Lei, Z. Carbon-supported platinum-decorated nickel nanoparticles for enhanced methanol oxidation in acid media. J. Solid State Electr. 2012, 16, 1049-1054. [CrossRef]

151. Ivanov, S.; Mintsouli, I.; Georgieva, J.; Armyanov, S.; Valova, E.; Kokkinidis, G; Sotiropoulos, S. Platinized $\mathrm{TiO}_{2}$ electrode coatings prepared by a two-step electrodeposition-galvanic replacement process for methanol oxidation in the dark and under UV light illumination. J. Electrochem. Sci. Eng. 2012, 2, 155-169.

152. Mintsouli, I.; Georgieva, J.; Papaderakis, A.; Tsiplakides, D.; Balomenou, S.; Sotiropoulos, S. Methanol oxidation at platinized copper particles prepared by galvanic replacement. J. Electrochem. Sci. Eng. 2016, 6, 17-28. [CrossRef]

153. Teng, X.; Du, W.; Wang, Q. Synthesis of Pt-containing metals alloy and hybrid nanowires and investigation of electronic structure using synchrotron-based X-ray absorption techniques. In Nanowires Fundamental Research; Hashim, A., Ed.; InTech: Shanghai, China, 2010; pp. 205-224.

154. Westsson, E.; Koper, G.J.M. How to determine the core-shell nature in bimetallic catalyst particles? Catalysts 2014, 4, 375-396. [CrossRef]

155. Sutter, E.; Jungjohann, K.; Bliznakov, S.; Courty, A.; Maisonhaute, E.; Tenney, S.; Sutter, P. In situ liquid-cell electron microscopy of silver-palladium galvanic replacement reactions on silver nanoparticles. Nat. Commun. 2014, 5, 4946. [CrossRef] [PubMed]

156. Guo, S.; Dong, S.; Wang, E. A general method for the rapid synthesis of hollow metallic or bimetallic nanoelectrocatalysts with urchinlike morphology. Chem. Eur. J. 2008, 14, 4689-4695. [CrossRef] [PubMed]

157. Zhou, X.-W.; Zhang, R.-H.; Zhou, Z.-Y.; Sun, S.-G. Preparation of PtNi hollow nanospheres for the electrocatalytic oxidation of methanol. J. Power Sources 2011, 196, 5844-5848. [CrossRef]

158. Song, C.; Zhang, J. Electrocatalytic oxygen reduction reaction. In PEM Fuel Cell Electrocatalysts and Catalyst Layers Fundamentals and Applications; Zhang, J., Ed.; Springer: London, UK, 2008; pp. 89-134.

159. Kinoshita, K. Electrochemical Oxygen Technology; Wiley-Interscience: Ney York, NY, USA, 1992.

160. Thompsett, D. Pt alloys as oxygen reduction catalysts. In Handbook of Fuel Cells: Fundamentals, Technology, Applications; Vielstich, W., Lamm, A., Gasteiger, H., Eds.; John Wiley and Sons Ltd.: London, UK, 2003; Volume 3, pp. 467-481.

161. Antolini, E.; Salgado, J.R.C.; Giz, M.J.; Gonzalez, E.R. The stability of Pt-M (M = first row transition metal) alloy catalysts and its effect on the activity in low temperature fuel cells. A literature review and tests on a Pt-Co catalyst. J. Power Sources 2006, 160, 957-968. [CrossRef]

162. Antolini, E. Formation of carbon-supported PtM alloys for low temperature fuel cells: A review. Mater. Chem. Phys. 2003, 78, 563-573. [CrossRef]

163. Shao, M.H.; Sasaki, K.; Liu, P.; Adzic, R.R. $\mathrm{Pd}_{3} \mathrm{Fe}$ and Pt monolayer-modified $\mathrm{Pd}_{3} \mathrm{Fe}$ electrocatalysts for oxygen reduction. Z. Phys. Chem. 2007, 221, 1175-1190. [CrossRef]

164. Shao, M.; Sasaki, K.; Marinkovic, N.S.; Zhang, L.; Adzic, R.R. Synthesis and characterization of platinum monolayer oxygen-reduction electrocatalysts with Co-Pd core-shell nanoparticle supports. Electrochem. Commun. 2007, 9, 2848-2853. [CrossRef]

165. Zhou, W.-P.; Sasaki, K.; Su, D.; Zhu, Y.; Wang, J.X.; Adzic, R.R. Gram-scale-synthesized Pd ${ }_{2}$ Co-supported Pt monolayer electrocatalysts for oxygen reduction reaction. J. Phys. Chem. C 2010, 114, 8950-8957. [CrossRef]

166. Gong, K.; Chen, W.-F.; Sasaki, K.; Su, D.; Vukmirovic, M.B.; Zhou, W.; Izzo, E.L.; Perez-Acosta, C.; Hirunsit, P.; Balbuena, P.B.; et al. Platinum-monolayer electrocatalysts: Palladium interlayer on IrCo alloy core improves activity in oxygen-reduction reaction. J. Electroanal. Chem. 2010, 649, 232-237. [CrossRef]

167. Sasaki, K.; Kuttiyiel, K.A.; Su, D.; Adzic, R.R. Platinum monolayer on IrFe core-shell nanoparticle electrocatalysts for the oxygen reduction reaction. Electrocatalysis 2011, 2, 134-140. [CrossRef]

168. Kuttiyiel, K.A.; Sasaki, K.; Choi, Y.; Su, D.; Liu, P.; Adzic, R.R. Bimetallic IrNi core platinum monolayer shell electrocatalysts for the oxygen reduction reaction. Energy Environ. Sci. 2012, 5, 5297-5304. [CrossRef]

169. Karan, H.I.; Sasaki, K.; Kuttiyiel, K.; Farberow, C.A.; Mavrikakis, M.; Adzic, R.R. Catalytic activity of platinum monolayer on iridium and rhenium alloy nanoparticles for the oxygen reduction reaction. ACS Catal. 2012, 2, 817-824. [CrossRef] 
170. Choi, Y.; Kuttiyiel, K.A.; Labis, J.P.; Sasaki, K.; Park, G.-G.; Yang, T.-H.; Adzic, R.R. Enhanced oxygen reduction activity of IrCu core platinum monolayer shell nano-electrocatalysts. Top. Catal. 2013, 56, 1059-1064. [CrossRef]

171. Shao, M.-H.; Sasaki, K.; Adzic, R.R. Pd-Fe nanoparticles as electrocatalysts for oxygen reduction. J. Am. Chem. Soc. 2006, 128, 3526-3527. [CrossRef] [PubMed]

172. Shao, M.H.; Huang, T.; Liu, P.; Zhang, J.; Sasaki, K.; Vukmirovic, M.B.; Adzic, R.R. Palladium monolayer and palladium alloy electrocatalysts for oxygen reduction. Langmuir 2006, 22, 10409-10415. [CrossRef] [PubMed]

173. Shao, M.; Liu, P.; Zhang, J.; Adzic, R.R. Origin of enhanced activity in palladium alloy electrocatalysts for oxygen reduction reaction. J. Phys. Chem. B 2007, 111, 6772-6775. [CrossRef] [PubMed]

174. Gong, K.; Su, D.; Adzic, R.R. Platinum-monolayer shell on $\mathrm{AuNi}_{0.5} \mathrm{Fe}$ nanoparticle core electrocatalyst with high activity and stability for the oxygen reduction reaction. J. Am. Chem. Soc. 2010, 132, 14364-14366. [CrossRef] [PubMed]

175. Xing, Y.; Cai, Y.; Vukmirovic, M.B.; Zhou, W.-P.; Karan, H.; Wang, J.X.; Adzic, R.R. Enhancing oxygen reduction reaction activity via $\mathrm{Pd}-\mathrm{Au}$ alloy sublayer mediation of $\mathrm{Pt}$ monolayer electrocatalysts. J. Phys. Chem. Lett. 2010, 1, 3238-3242. [CrossRef]

176. Kuttiyiel, K.A.; Sasaki, K.; Su, D.; Vukmirovic, M.B.; Marinkovic, N.S.; Adzic, R.R. Pt monolayer on Au-stabilized PdNi core-shell nanoparticles for oxygen reduction reaction. Electrochim. Acta 2013, 110, 267-272. [CrossRef]

177. Chen, G.; Kuttiyiel, K.A.; Su, D.; Li, M.; Wang, C.-H.; Buceta, D.; Du, C.; Cao, Y.; Yin, G.; Sasaki, K.; et al. Oxygen reduction kinetics on Pt monolayer shell highly affected by the structure of bimetallic AuNi cores. Chem. Mater. 2016, 28, 5274-5281. [CrossRef]

178. Kuttiyiel, K.A.; Choi, Y.; Hwang, S.-M.; Park, G.-G.; Yang, T.-H.; Su, D.; Sasaki, K.; Liu, P.; Adzic, R.R. Enhancement of the oxygen reduction on nitride stabilized Pt-M $(\mathrm{M}=\mathrm{Fe}, \mathrm{Co}$, and $\mathrm{Ni})$ core-shell nanoparticle electrocatalysts. Nano Energy 2015, 13, 442-449. [CrossRef]

179. Hu, J.; Kuttiyiel, K.A.; Sasaki, K.; Su, D.; Yang, T.H.; Park, G.G.; Zhang, C.; Chen, G.; Adzic, R.R. Pt monolayer shell on nitrided alloy core-A path to highly stable oxygen reduction catalyst. Catalysts 2015, 5, 1321-1332. [CrossRef]

180. Knupp, S.L.; Vukmirovic, M.B.; Haldar, P.; Herron, J.A.; Mavrikakis, M.; Adzic, R.R. Platinum Monolayer Electrocatalysts for $\mathrm{O}_{2}$ Reduction: Pt Monolayer on Carbon-Supported PdIr Nanoparticles. Electrocatalysis 2010, 1, 213-223. [CrossRef]

181. Sun, Z.; Masa, J.; Xia, W.; König, D.; Ludwig, A.; Li, Z.-A.; Farle, M.; Schuhmann, W.; Muhler, M. Rapid and surfactant-free synthesis of bimetallic Pt-Cu nanoparticles simply via ultrasound-assisted redox replacement. ACS Catal. 2012, 2, 1647-1653. [CrossRef]

182. Jung, N.; Sohn, Y.; Park, J.H.; Nahm, K.S.; Kim, P.; Yoo, S.J. High-performance PtCu $\mathrm{u}_{x}$ at Pt core-shell nanoparticles decorated with nanoporous Pt surfaces for oxygen reduction reaction. Appl. Catal. B 2016, 196, 199-206. [CrossRef]

183. Chen, D.; Ye, F.; Liu, H.; Yang, J. Cage-bell Pt-Pd nanostructures with enhanced catalytic properties and superior methanol tolerance for oxygen reduction reaction. Sci. Rep. 2016, 6, 24600. [CrossRef] [PubMed]

184. Guo, H.; Liu, X.; Bai, C.; Chen, Y.; Wang, L.; Zheng, M.; Dong, Q.; Peng, D.-L. Effect of component distribution and nanoporosity in $\mathrm{CuPt}$ nanotubes on electrocatalysis of the oxygen reduction reaction. ChemSusChem 2015, 8, 486-494. [CrossRef] [PubMed]

185. Wu, J.; Peng, Z.; Yang, H. Supportless oxygen reduction electrocatalysts of CoCuPt hollow nanoparticles. Philos. Trans. A 2010, 368, 4261-4274. [CrossRef] [PubMed]

186. Bae, S.J.; Yoo, S.J.; Lim, Y.; Kim, S.; Lim, Y.; Choi, J.; Nahm, K.S.; Hwang, S.J.; Lim, T.-H.; Kim, S.-K.; et al. Facile preparation of carbon-supported PtNi hollow nanoparticles with high electrochemical performance. J. Mater. Chem. 2012, 22, 8820-8825. [CrossRef]

187. Dubau, L.; Asset, T.; Chattot, R.; Bonnaud, C.; Vanpeene, V.; Nelayah, J.; Maillard, F. Tuning the performance and the stability of porous hollow PtNi/C nanostructures for the oxygen reduction reaction. ACS Catal. 2015, 5, 5333-5341. [CrossRef]

188. Nagai, H.; Aso, H.; Kawabuchi, M.; Kondo, T. Electrochemical construction of Ni and co core-Pt shell nanoparticles as catalysts for oxygen reduction reaction. ECS Trans. 2013, 58, 27-31. [CrossRef] 
189. Liu, M.; Chi, F.; Liu, J.; Song, Y.; Wang, F. A novel strategy to synthesize bimetallic Pt-Ag particles with tunable nanostructures and their superior electrocatalytic activities toward the oxygen reduction reaction. RSC Adv. 2016, 6, 62327-62335. [CrossRef]

190. Fu, T.; Fang, J.; Wang, C.; Zhao, J. Hollow porous nanoparticles with Pt skin on a Ag-Pt alloy structure as a highly active electrocatalyst for the oxygen reduction reaction. J. Mater. Chem. A 2016, 4, 8803-8811. [CrossRef]

191. Chen, D.; Li, C.; Liu, H.; Ye, F.; Yang, J. Core-shell Au@Pd nanoparticles with enhanced catalytic activity for oxygen reduction reaction via core-shell Au@Ag/Pd constructions. Sci. Rep. 2015, 5, 11949. [CrossRef] [PubMed]

192. Wang, M.; Zhang, W.; Wang, J.; Wexler, D.; Poynton, S.D.; Slade, R.C.T.; Liu, H.; Winther-Jensen, B.; Kerr, R.; Shi, D.; et al. PdNi hollow nanoparticles for improved electrocatalytic oxygen reduction in alkaline environments. ACS Appl. Mater. Interfaces 2013, 5, 12708-12715. [CrossRef] [PubMed]

193. Hsu, C.; Huang, C.; Hao, Y.; Liu, F. Synthesis of highly active and stable Au-PtCu core-shell nanoparticles for oxygen reduction reaction. Phys. Chem. Chem. Phys. 2012, 14, 14696-14701. [CrossRef] [PubMed]

194. Ye, F.; Liu, H.; Hu, W.; Zhong, J.; Chen, Y.; Cao, H.; Yang, J. Heterogeneous Au-Pt nanostructures with enhanced catalytic activity toward oxygen reduction. Dalton Trans. 2012, 41, 2898-2903. [CrossRef] [PubMed]

195. Zhang, H.; Jin, M.; Wang, J.; Li, W.; Camargo, P.H.C.; Kim, M.J.; Yang, D.; Xie, Z.; Xia, Y. Synthesis of Pd-Pt bimetallic nanocrystals with a concave structure through a bromide-induced galvanic replacement reaction. J. Am. Chem. Soc. 2011, 133, 6078-6089. [CrossRef] [PubMed]

196. Yang, J.; Cheng, C.H.; Zhou, W.; Lee, J.Y.; Liu, Z. Methanol-tolerant heterogeneous PdCo@PdPt/C electrocatalyst for the oxygen reduction reaction. Fuel Cells 2010, 10, 907-913. [CrossRef]

197. Yaldagard, M.; Seghatoleslami, N.; Jahanshahi, M. Oxygen reduction reaction activity improvement in $\mathrm{Cu} /$ PtPd nanocatalyst based on core-shell structured through electrochemical synthesis on porous gas diffusion electrodes in polymer electrolyte membrane fuel cells. J. Nano Res. 2015, 31, 62-80. [CrossRef]

198. Caixia, X.; Yan, Z.; Liqiang, X.; Xiufang, B.; Houyi, M.; Yi, D. Nanotubular mesoporous PdCu bimetallic electrocatalysts toward oxygen reduction reaction. Chem. Mater. 2009, 21, 3110-3116.

199. Stamenkovic, V.R.; Mun, B.S.; Mayrhofer, K.J.J.; Ross, P.N.; Markovic, N.M. Effect of surface composition on electronic structure, stability, and electrocatalytic properties of Pt-transition metal alloys: Pt-skin versus Pt-skeleton surfaces. J. Am. Chem. Soc. 2006, 128, 8813-8819. [CrossRef] [PubMed]

200. Stamenkovic, V.R.; Mun, B.S.; Arenz, M.; Mayrhofer, K.J.J.; Lucas, C.A.; Wang, G.; Ross, P.N.; Markovic, N.M. Trends in electrocatalysis on extended and nanoscale Pt-bimetallic alloy surfaces. Nat. Mater. 2007, 6, 241-247. [CrossRef] [PubMed]

201. Wakisaka, M.; Mitsui, S.; Hirose, Y.; Kawashima, K.; Uchida, H.; Watanabe, M. Electronic structures of Pt-Co and Pt-Ru alloys for CO-tolerant anode catalysts in polymer electrolyte fuel cells studied by EC-XPS. J. Phys. Chem. B 2006, 110, 23489-23496. [CrossRef] [PubMed]

202. Paulus, U.A.; Wokaun, A.; Scherer, G.G.; Schmidt, T.J.; Stamenkovic, V.; Radmilovic, V.; Markovic, N.M.; Ross, P.N. Oxygen reduction on carbon-supported Pt-Ni and Pt-Co alloy catalysts. J. Phys. Chem. B 2002, 106, 4181-4191. [CrossRef]

203. Paulus, U.A.; Wokaun, A.; Scherer, G.G.; Schmidt, T.J.; Stamenkovic, V.; Markovic, N.M.; Ross, P.N. Oxygen reduction on high surface area Pt-based alloy catalysts in comparison to well defined smooth bulk alloy electrodes. Electrochim. Acta 2002, 47, 3787-3798. [CrossRef]

204. Stamenkovic, V.R.; Schmidt, T.J.; Ross, P.N.; Markovic, N.M. Surface composition effects in electrocatalysis: Kinetics of oxygen reduction on well-defined $\mathrm{Pt}_{3} \mathrm{Ni}$ and $\mathrm{Pt}_{3} \mathrm{Co}$ alloy surfaces. J. Phys. Chem. B 2002, 106, 11970-11979. [CrossRef]

205. Stamenkovic, V.R.; Mun, B.S.; Mayrhofer, K.J.J.; Ross, P.N.; Markovic, N.M.; Rossmeil, J.; Greeley, J.; Nørskov, J.K. Changing the activity of electrocatalysts for oxygen reduction by tuning the surface electronic structure. Angew. Chem. Int. Ed. 2006, 45, 2897-2901. [CrossRef] [PubMed]

206. Stamenkovic, V.R.; Fowler, B.; Mun, B.S.; Wang, G.; Ross, P.N.; Lucas, C.A.; Markovic, N.M. Improved oxygen reduction activity on $\mathrm{Pt}_{3} \mathrm{Ni}(111)$ via increased surface site availability. Science 2007, 315, 493-497. [CrossRef] [PubMed]

207. Wakisaka, M.; Suzuki, H.; Mitsui, S.; Uchida, H.; Watanabe, M. Increased oxygen coverage at Pt-Fe alloy cathode for the enhanced oxygen reduction reaction studied by EC-XPS. J. Phys. Chem. C 2008, 112, 2750-2755. [CrossRef] 
208. Lamy, C.; Léger, J.-M.; Srinivasan, S. Direct methanol fuel cells: From a twentieth century electrochemist's dream to a twenty-first century emerging technology. In Modern Aspects of Electrochemistry; Bockris, J.O.M., Conway, B.E., Eds.; Plenum Press: Plattsburgh, NY, USA, 2000; Volume 34, pp. 53-118.

209. Hamnett, A. Direct methanol fuel cells (DMFC). In Handbook of Fuel Cells: Fundamentals Technology and Applications; Vielstich, W., Lamm, A., Gasteiger, H.A., Eds.; Wiley: Chichester, UK, 2003; Volume 1, pp. 305-316.

210. Beden, B.; Kadirgan, F.; Lamy, C.; Léger, J.-M. Electrocatalytic oxidation of methanol on platinum-based binary electrodes. J. Electroanal. Chem. 1981, 127, 75-85. [CrossRef]

211. Chrzanowski, W.; Kim, H.; Wieckowski, A. Enhancement in methanol oxidation by spontaneously deposited ruthenium on low-index platinum electrodes. Catal. Lett. 1998, 50, 69-75. [CrossRef]

212. Lamy, C.; Lima, A.; LeRhun, V.; Delime, F.; Coutencau, C.; Léger, J.-M. Recent advances in the development of direct alcohol fuel cells (DAFC). J. Power Sources 2002, 105, 283-296. [CrossRef]

213. Antolini, E.; Lopes, T.; Gonzalez, E.R. An overview of platinum-based catalysts as methanol-resistant oxygen reduction materials for direct methanol fuel cells. J. Alloy. Compd. 2008, 461, 253-262. [CrossRef]

214. Antolini, E.; Salgado, J.R.C.; dos Santos, A.M.; Gonzalez, E.R. The methanol oxidation reaction on platinum alloys with the first row transition metals: The case of Pt-Co and -Ni alloy electrocatalysts for DMFCs: A short review. Appl. Catal. B 2006, 63, 137-149. [CrossRef]

215. Antolini, E. Platinum-based ternary catalysts for low temperature fuel cells. Part I. Preparation methods and structural characteristics. Appl. Catal. B 2007, 74, 324-336. [CrossRef]

216. Sasaki, K.; Adzic, R.R. Monolayer-level Ru- and $\mathrm{NbO}_{2}$-supported platinum electrocatalysts for methanol oxidation. J. Electrochem. Soc. 2008, 155, B180-B186. [CrossRef]

217. Liu, H.; Adzic, R.R.; Wong, S.S. Multifunctional ultrathin $\mathrm{Pd}_{x} \mathrm{Cu}_{1-x}$ and $\mathrm{Pt} \sim \mathrm{Pd}_{x} \mathrm{Cu}_{1-x}$ one-dimensional nanowire motifs for various small molecule oxidation reactions. ACS Appl. Mater. Interfaces 2015, 7, 26145-26157. [CrossRef] [PubMed]

218. Ando, Y.; Sasaki, K.; Adzic, R. Electrocatalysts for methanol oxidation with ultra low content of Pt and Ru. Electrochem. Commun. 2009, 11, 1135-1138. [CrossRef]

219. Kusnetsov, V.V.; Podlovchenko, B.I.; Shakurov, R.I.; Kavyrshina, K.V.; Lyahenko, S.E. NPt ${ }^{0}\left(\mathrm{H}_{x-2 n} \mathrm{MoO}_{3}\right)$ as a promising catalyst for the oxidation of methanol. Synthesis and electrocatalytic properties. Int. J. Hydrogen Energy 2014, 39, 829-836. [CrossRef]

220. Zhou, X.-W.; Gan, Y.-L.; Sun, S.-G. Studies of oxidation processes of methanol on hollow CoPt nanospheres and in situ electrochemical Fourier transform infrared spectroscopy. Acta Phys. Chim. Sin. 2012, 28, 2071-2076.

221. Zhou, X.-W.; Chen, Q.-S.; Zhou, Z.-Y.; Sun, S.-G. Synthesis, electrocatalytic and anomalous IR properties of hollow CoPt chainlike nanomaterials. J. Nanosci. Nanotechnol. 2009, 9, 2392-2397. [CrossRef] [PubMed]

222. Chen, Q.-S.; Sun, S.-G.; Zhou, Z.-Y.; Chen, Y.-X.; Deng, S.-B. CoPt nanoparticles and their catalytic properties in electrooxidation of $\mathrm{CO}$ and $\mathrm{CH}_{3} \mathrm{OH}$ studied by in situ FTIRS. Phys. Chem. Chem. Phys. 2008, 10, 3645-3654. [CrossRef] [PubMed]

223. Liu, J.; Xia, T.; Wang, S.; Yang, G.; Dong, B.; Wang, C.; Ma, Q.; Sun, Y.; Wang, R. Oriented-assembly of hollow FePt nanochains with tunable catalytic and magnetic properties. Nanoscale 2016, 8, 11432-11440. [CrossRef] [PubMed]

224. Guo, S.; Fang, Y.; Dong, S.; Wang, E. High-efficiency and low-cost hybrid nanomaterial as enhancing electrocatalyst: Spongelike Au/Pt core/shell nanomaterial with hollow cavity. J. Phys. Chem. C 2007, 111, 17104-17109. [CrossRef]

225. Sieben, J.M.; Alvarez, A.E.; Comignani, V.; Duarte, M.M.E. Methanol and ethanol oxidation on carbon supported nanostructured $\mathrm{Cu}$ core Pt-Pd shell electrocatalysts synthesized via redox displacement. Int. J. Hydrogen Energy 2014, 39, 11547-11556. [CrossRef]

226. Li, Q.; Xu, P.; Zhang, B.; Wu, G.; Zhao, H.; Fu, E.; Wang, H.-L. Self-supported Pt nanoclusters via galvanic replacement from $\mathrm{Cu}_{2} \mathrm{O}$ nanocubes as efficient electrocatalysts. Nanoscale 2013, 5, 7397-7402. [CrossRef] [PubMed]

227. Hosseini, M.G.; Abdolmaleki, M.; Ashrafpoor, S. Methanol electro-oxidation on a porous nanostructured $\mathrm{Ni} / \mathrm{Pd}-\mathrm{Ni}$ electrode in alkaline media. Chin. J. Catal. 2013, 34, 1712-1719. [CrossRef]

228. Zhao, D.; Yan, B.; Xu, B.-Q. Proper alloying of Pt with underlying Ag nanoparticles leads to dramatic activity enhancement of Pt electrocatalyst. Electrochem. Commun. 2008, 10, 884-887. [CrossRef] 
229. Zhang, W.; Yang, J.; Lu, X. Tailoring galvanic replacement reaction for the preparation of Pt/ Ag bimetallic hollow nanostructures with controlled number of voids. ACS Nano 2012, 6, 7397-7405. [CrossRef] [PubMed]

230. Zheng, F.; Luk, S.-Y.; Kwong, T.-L.; Yung, K.-F. Synthesis of hollow PtAg alloy nanospheres with excellent electrocatalytic performances towards methanol and formic acid oxidations. RSC Adv. 2016, 6, 44902-44907. [CrossRef]

231. Rashid, M.; Jun, T.-S.; Jung, Y.; Kim, Y.S. Bimetallic core-shell Ag@Pt nanoparticle-decorated MWNT electrodes for amperometric $\mathrm{H}_{2}$ sensors and direct methanol fuel cells. Sens. Actuators B 2014, 208, 7-13. [CrossRef]

232. Zhao, D.; Wang, Y.-H.; Yan, B.; Xu, B.-Q. Manipulation of Pt Ag nanostructures for advanced electrocatalyst. J. Phys. Chem. C 2009, 113, 1242-1250. [CrossRef]

233. Ishikawa, Y.; Liao, M.-S.; Cabrera, C.R. A theory-guided design of bimetallic nanoparticle catalysts for fuel cell applications. In Computational Materials Science, Theoretical and Computational Chemistry Series; Leszzynski, J., Ed.; Elsevier Science: Amsterdam, The Netherlands, 2004; Volume 15, pp. 125-154.

234. Yu, X.; Pickup, P.G. Recent advances in direct formic acid fuel cells (DFAFC). J. Power Sources 2008, 182, 124-132. [CrossRef]

235. Jiang, K.; Zhang, H.-X.; Zou, S.; Cai, W.-B. Electrocatalysis of formic acid on palladium and platinum surfaces: From fundamental mechanisms to fuel cell applications. Phys. Chem. Chem. Phys. 2014, 16, 20360-20376. [CrossRef] [PubMed]

236. Zhang, J.; Qiu, C.; Ma, H.; Liu, X. Facile fabrication and unexpected electrocatalytic activity of palladium thin films with hierarchical architectures. J. Phys. Chem. C 2008, 112, 13970-13975. [CrossRef]

237. Liu, Z.; Zhao, B.; Guo, C.; Sun, Y.; Xu, F.; Yang, H.; Li, Z. Novel hybrid electrocatalyst with enhanced performance in alkaline media: Hollow $\mathrm{Au} / \mathrm{Pd}$ core/shell nanostructures with a raspberry surface. J. Phys. Chem. C 2009, 113, 16766-16771. [CrossRef]

238. Gu, X.; Cong, X.; Ding, Y. Platinum-decorated Au porous nanotubes as highly efficient catalysts for formic acid electro-oxidation. ChemPhysChem 2010, 11, 841-846. [CrossRef] [PubMed]

239. Li, R.; Hao, H.; Cai, W.-B.; Huang, T.; Yu, A. Preparation of carbon supported Pd-Pb hollow nanospheres and their electrocatalytic activities for formic acid oxidation. Electrochem. Commun. 2010, 12, 901-904. [CrossRef]

240. Lu, X.; McKiernan, M.; Peng, Z.; Lee, E.P.; Yang, H.; Xia, Y. Noble-metal nanotubes prepared via a galvanic replacement reaction between $\mathrm{Cu}$ nanowires and aqueous $\mathrm{HAuCl}_{4}, \mathrm{H}_{2} \mathrm{PtCl}_{6}$, or $_{\mathrm{Na}_{2}} \mathrm{PdCl}_{4}$. Sci. Adv. Mater. 2010, 2, 413-420. [CrossRef]

241. Lu, Y.; Chen, W. Nanoneedle-covered Pd-Ag nanotubes: High electrocatalytic activity for formic acid oxidation. J. Phys. Chem. C 2010, 114, 21190-21200. [CrossRef]

242. Qiu, C.; Guo, Y.; Zhang, J.; Ma, H.; Cai, Y. Bimetallic Pt-Au thin film electrocatalysts with hierarchical structures for the oxidation of formic acid. Mater. Chem. Phys. 2011, 127, 484-488. [CrossRef]

243. Dai, L.; Zou, S. Enhanced formic acid oxidation on Cu-Pd nanoparticles. J. Power Sources 2011, 196, 9369-9372. [CrossRef]

244. Jiang, Y.; Lu, Y.; Han, D.; Zhang, Q.; Niu, L. Hollow Ag@Pd core-shell nanotubes as highly active catalysts for the electro-oxidation of formic acid. Nanotechnology 2012, 23, 105609. [CrossRef] [PubMed]

245. Li, Y.; Wu, S.; Cui, X.; Wang, L.; Shi, X. Ultralow platinum-loading bimetallic nanoflowers: Fabrication and high-performance electrocatalytic activity towards the oxidation of formic acid. Electrochem. Commun. 2012, 25, 19-22. [CrossRef]

246. Lee, D.; Jang, H.Y.; Hong, S.; Park, S. Synthesis of hollow and nanoporous gold/platinum alloy nanoparticles and their electrocatalytic activity for formic acid oxidation. J. Colloid Interface Sci. 2012, 388, 74-79. [CrossRef] [PubMed]

247. Zhao, H.; Zhao, T.S. Highly active carbon nanotube-supported Pd electrocatalyst for oxidation of formic acid prepared by etching copper template method. Int. J. Hydrogen Energy 2013, 38, 1391-1396. [CrossRef]

248. Ren, M.; Zhou, Y.; Tao, F.; Zou, Z.; Akins, D.L.; Yang, H. Controllable modification of the electronic structure of carbon-supported core-shell Cu@Pd catalysts for formic acid oxidation. J. Phys. Chem. C 2014, 118, 12669-12675. [CrossRef]

249. Rasouli, H.; Tabaian, S.H.; Rezaei, M. Galvanic replacement of electrodeposited nickel by palladium and investigation of the electrocatalytic activity of synthesized $\mathrm{Pd} /(\mathrm{Ni})$ for hydrogen evolution and formic acid oxidation. RSC Adv. 2016, 6, 22500-22510. [CrossRef] 
250. Yu, B.; Wen, W.; Li, W.; Yang, Y.; Hou, D.; Liu, C. Fabrication of high performance carbon-supported ternary $\mathrm{Pd}-\mathrm{Cu}-\mathrm{Fe}$ electrocatalysts for formic acid electrooxidation via partly galvanic sacrifice of tunable binary Cu-Fe alloy templates. Electrochim. Acta 2016, 196, 223-230. [CrossRef]

251. Hu, J.; Li, H.; Gan, Q.-M.; Li, Y.-J. Three-dimensional porous Au nanocoral structure decorated with Pt submonolayer via galvanic displacement of copper adatoms for electrooxidation of formic acid. Russ. J. Electrochem. 2016, 52, 355-361. [CrossRef]

252. Mkwizu, T.S.; Mathe, M.K.; Cukrowski, I. Multilayered nanoclusters of platinum and gold: Insights on electrodeposition pathways, electrocatalysis, surface and bulk compositional properties. J. Electrochem. Soc. 2013, 160, H529-H546. [CrossRef]

253. Zhou, Y.; Du, C.; Han, G.; Gao, Y.; Yin, G. Ultra-low Pt decorated PdFe alloy nanoparticles for formic acid electro-oxidation. Electrochim. Acta 2016, 217, 203-209. [CrossRef]

254. Wang, Y.; Zou, S.; Cai, W.-B. Recent advances on electro-oxidation of ethanol on Pt- and Pd-based catalysts: From reaction mechanisms to catalytic materials. Catalysts 2015, 5, 1507-1534. [CrossRef]

255. Brouzgou, A.; Podias, A.; Tsiakaras, P. PEMFCs and AEMFCs directly fed with ethanol: A current status comparative review. J. Appl. Electrochem. 2013, 43, 119-136. [CrossRef]

256. Prieto, M.J.; Rodrigues Filho, U.P.; Landers, R.; Tremiliosi-Filho, G. The ethanol electrooxidation at Pt layers deposited on polycrystalline Au. Phys. Chem. Chem. Phys. 2012, 14, 599-606. [CrossRef] [PubMed]

257. Li, C.; Su, Y.; Lv, X.; Shi, H.; Yang, X.; Wang, Y. Enhanced ethanol electrooxidation of hollow Pd nanospheres prepared by galvanic exchange reactions. Mater. Lett. 2012, 69, 92-95. [CrossRef]

258. Tamasauskait-Tamasuinaite, L.; Balčiunaite, A.; Vaiciukevičiene, A.; Selskis, A.; Pakštas, V. Investigation of nanostructured platinum-nickel supported on the titanium surface as electrocatalysts for alkaline fuel cells. J. Power Sources 2012, 208, 242-247. [CrossRef]

259. Song, H.M.; Anjum, D.H.; Sougrat, R.; Hedhili, M.N.; Khashab, N.M. Hollow Au@Pd and Au@Pt core-shell nanoparticles as electrocatalysts for ethanol oxidation reactions. J. Mater. Chem. 2012, 22, 25003-25010. [CrossRef]

260. Huang, S.-J.; Chen, P.-Y. Fabrication of macroporous Pt and PtAu electrodes for electrochemical application through galvanic replacement at macroporous $\mathrm{Cu}$ electrode electrodeposited at polystyrene template from room temperature ionic liquid. Electrochim. Acta 2013, 89, 180-190. [CrossRef]

261. Abbasi, N.; Shahbazi, P.; Kiani, A. Electrocatalytic oxidation of ethanol at Pd/Ag nanodendrites prepared via low support electrodeposition and galvanic replacement. J. Mater. Chem. A 2013, 1, 9966-9972. [CrossRef]

262. Hong, W.; Liu, Y.; Wang, J.; Wang, E. A new kind of highly active hollow flower-like NiPdPt nanoparticles supported by multiwalled-carbon nanotubes toward ethanol electrooxidation. J. Power Sources 2013, 241, 751-755. [CrossRef]

263. Chen, D.; Zhao, Y.; Fan, Y.; Peng, X.; Wang, X.; Tian, J. Synthesis of Ni@PbPt supported on graphene by galvanic displacement reaction for improving ethanol electro-oxidation. J. Mater. Chem. A 2013, 1, 13227-13232. [CrossRef]

264. Sieben, J.M.; Comignani, V.; Alvarez, A.E.; Duarte, M.M.E. Synthesis and characterization of Cu core $\mathrm{Pt}-\mathrm{Ru}$ shell nanoparticles for the electro-oxidation of alcohols. Int. J. Hydrogen Energy 2014, 39, 8667-8674. [CrossRef]

265. Cai, J.; Zeng, Y.; Guo, Y. Copper@palladium-copper core-shell nanospheres as a highly effective electrocatalyst for ethanol electro-oxidation in alkaline media. J. Power Sources 2014, 270, 257-261. [CrossRef]

266. Peng, C.; Hu, Y.; Liu, M.; Zheng, Y. Hollow raspberry-like PdAg alloy nanospheres: High electrocatalytic activity for ethanol oxidation in alkaline media. J. Power Sources 2015, 278, 69-75. [CrossRef]

267. Chen, Y.; Lai, S.; Jiang, S.; Liu, Y.; Fu, C.; Li, A.; Chen, Y.; Lai, X.; Hu, J. Synthesis and enhanced electrocatalytic properties of Au/Pd/Pt nanohollows. Mater. Lett. 2015, 157, 15-18. [CrossRef]

268. Shi, Q.; Zhang, P.; Li, Y.; Xia, H.; Wang, D.; Tao, X. Synthesis of open-mouthed, yolk-shell Au@AgPd nanoparticles with access to interior surfaces for enhanced electrocatalysis. Chem. Sci. 2015, 6, 4350-4357. [CrossRef]

269. Gnanaprakasam, P.; Jeena, S.E.; Selvaraju, T. Hierarchical electroless Pt deposition at Au decorated reduced graphene oxide via a galvanic exchanged process: An electrocatalytic nanocomposite with enhanced mass activity for methanol and ethanol oxidation. J. Mater. Chem. A 2015, 3, 18010-18018. [CrossRef]

270. Zhao, T.-T.; Wang, H.; Han, X.; Jiang, K.; Lin, H.; Xie, Z.; Cai, W.-B. A comparative investigation of electrocatalysis at $\mathrm{Pt}$ monolayers on shape-controlled $\mathrm{Au}$ nanocrystals: Facet effect versus strain effect. J. Mater. Chem. A 2016, 4, 15845-15850. [CrossRef] 
271. Liu, P.; Cheng, Z.; Ma, L.; Zhang, M.; Qiu, Y.; Chen, M.; Cheng, F. Cuprous oxide template synthesis of hollow-cubic $\mathrm{Cu}_{2} \mathrm{O} @ \mathrm{Pd}_{x} \mathrm{Ru}_{y}$ nanoparticles for ethanol electrooxidation in alkaline media. RSC Adv. 2016, 6, 76684-76690. [CrossRef]

272. Bin, D.; Yang, B.; Zhang, K.; Wang, C.; Wang, J.; Zhong, J.; Feng, Y.; Guo, J.; Du, Y. Design of PdAg hollow nanoflowers through galvanic replacement and their application for ethanol electrooxidation. Chem. Eur. J. 2016, 22, 16642-16647. [CrossRef] [PubMed]

273. Jo, Y.-G.; Kim, S.-M.; Kim, J.-W.; Lee, S.-Y. Composition-tuned porous Pd-Ag bimetallic dendrites for the enhancement of ethanol oxidation reactions. J. Alloys Compd. 2016, 688, 447-453. [CrossRef]

274. Peng, C.; Yang, W.; Wu, E.; Ma, Y.; Zheng, Y.; Nie, Y.; Zhang, H.; Xu, J. PdAg alloy nanotubes with porous walls for enhanced electrocatalytic activity towards ethanol electrooxidation in alkaline media. J. Alloys Compd. 2017, 698, 250-258. [CrossRef]

275. Guerrini, E.; Trasatti, S. Electrocatalysis in water electrolysis. In Catalysis for Sustainable Energy Production; Barbaro, P., Bianchini, C., Eds.; Wiley-VCH Verlag GmbH \& Co. KGaA: Weinheim, Germany, 2009; pp. 235-269.

276. Lamy, C. From hydrogen production by water electrolysis to its utilization in a PEM fuel cell or in a SO fuel cell: Some considerations on the energy efficiencies. Int. J. Hydrogen Energy 2016, 41, 15415-15425. [CrossRef]

277. Bansal, V.; O'Mullane, A.P.; Bhargava, S.K. Galvanic replacement mediated synthesis of hollow Pt nanocatalysts: Significance of residual $\mathrm{Ag}$ for the $\mathrm{H}_{2}$ evolution reaction. Electrochem. Commun. 2009, 11, 1639-1642. [CrossRef]

278. Raoof, J.-B.; Ojani, R.; Kiani, A.; Rashid-Nadimi, S. Fabrication of highly porous Pt coated nanostructured $\mathrm{Cu}$-foam modified copper electrode and its enhanced catalytic ability for hydrogen evolution reaction. Int. J. Hydrogen Energy 2010, 35, 452-458. [CrossRef]

279. Raoof, J.B.; Ojani, R.; Esfeden, S.A.; Nadimi, S.R. Fabrication of bimetallic Cu/Pt nanoparticles modified glassy carbon electrode and its catalytic activity toward hydrogen evolution reaction. Int. J. Hydrogen Energy 2010, 35, 3937-3944. [CrossRef]

280. Ojani, R.; Raoof, J.B.; Hasheminejad, E. One-step electroless deposition of Pd/Pt bimetallic microstructures by galvanic replacement on copper substrate and investigation of its performance for the hydrogen evolution reaction. Int. J. Hydrogen Energy 2013, 38, 92-99. [CrossRef]

281. Rezaei, B.; Mokhtarianpour, M.; Ensafi, A.A. Fabricated of bimetallic Pd/Pt nanostructure deposited on copper nanofoam substrate by galvanic replacement as an effective electrocatalyst for hydrogen evolution reaction. Int. J. Hydrogen Energy 2015, 40, 6754-6762. [CrossRef]

282. Shen, Y.; Lua, A.C.; Xi, J.; Qiu, X. Ternary platinum-copper-nickel nanoparticles anchored to hierarchical carbon supports as free-standing hydrogen evolution electrodes. ACS Appl. Mater. Interfaces 2016, 8, 3464-3472. [CrossRef] [PubMed]

283. Tölle, R.; Otto, A. Hydrogen-evolution and -oxidation on $\mathrm{Ag}(111)$ covered by Pt. Surf. Sci. 2005, 597, 110-118. [CrossRef]

284. Mitchell, P.C.H.; Wolohan, P.; Thompsett, D.; Cooper, S.J. Experimental and theoretical studies of fuel cell catalysts: Density functional theory calculations of $\mathrm{H}_{2}$ dissociation and $\mathrm{CO}$ chemisorption on fuel cell metal dimers. J. Mol. Catal. A 1997, 119, 223-233. [CrossRef]

285. Najdovski, I.; O'Mullane, A.P.; Bhargava, S.K. Electrochemical properties of galvanically replaced iron nanocubes with gold and palladium. Electrochem. Commun. 2010, 12, 1535-1538. [CrossRef]

286. Trasatti, S. Work function, electronegativity, and electrochemical behaviour of metals. III. Electrolytic hydrogen evolution in acid solutions. J. Electroanal. Chem. 1972, 39, 163-184. [CrossRef]

287. Greeley, J.; Jaramillo, T.F.; Bonde, J.; Chorkendorff, I.B.; Nørskov, J.K. Computational high-throughput screening of electrocatalytic materials for hydrogen evolution. Nat. Mater. 2006, 5, 909-913. [CrossRef] [PubMed]

288. Greeley, J.; Nørskov, J.K. Large-scale, density functional theory-based screening of alloys for hydrogen evolution. Surf. Sci. 2007, 601, 1590-1598. [CrossRef]

289. Greeley, J.; Mavrikakis, M. Alloy catalysts designed from first principles. Nat. Mater. 2004, 3, 810. [CrossRef] [PubMed]

290. Greeley, J.; Mavrikakis, M. Near-surface alloys for hydrogen fuel cell applications. Catal. Today 2006, 111, 52-58. [CrossRef] 
291. Elbert, K.; Hu, J.; Ma, Z.; Zhang, Y.; Chen, G.; An, W.; Liu, P.; Isaacs, H.S.; Adzic, R.R.; Wang, J.X. Elucidating hydrogen oxidation/evolution kinetics in base and acid by enhanced activities at the optimized Pt shell thickness on the Ru core. ACS Catal. 2015, 5, 6764-6772. [CrossRef]

292. Shao, Y.; Liu, J.; Wang, Y. Oxygen electrocatalysts for water electrolyzers and reversible fuel cells: Status and perspective. Energy Environ. Sci. 2012, 5, 9331-9344.

293. Hu, S.; Goenaga, G.; Melton, C.; Zawodzinski, T.A.; Mukherjee, D. PtCo/CoO $x$ nanocomposites: Bifunctional electrocatalysts for oxygen reduction and evolution reactions synthesized via tandem laser ablation synthesis in solution-galvanic replacement reactions. Appl. Catal. B 2016, 182, 286-296. [CrossRef]

294. Pei, J.; Mao, J.; Liang, X.; Chen, C.; Peng, Q.; Wang, D.; Li, Y. Ir-Cu nanoframes: One-pot synthesis and efficient electrocatalysts for oxygen evolution reaction. Chem. Commun. 2016, 52, 3793-3796. [CrossRef] [PubMed]

295. Wang, C.; Sui, Y.; Xiao, G.; Yang, X.; Wei, Y.; Zou, G.; Zou, B. Synthesis of Cu-Ir nanocages with enhanced electrocatalytic activity for the oxygen evolution reaction. J. Mater. Chem. A 2015, 3, 19669-19673. [CrossRef]

296. Yoon, D.; Bang, S.; Park, J.; Kim, J.; Baik, H.; Yang, H.; Lee, K. One pot synthesis of octahedral \{111\} CuIr gradient alloy nanocrystals with a Cu-rich core and an Ir-rich surface and their usage as efficient water splitting catalyst. CrystEngComm 2015, 17, 6843-6847. [CrossRef]

297. Nong, H.N.; Gan, L.; Willinger, E.; Teschner, D.; Strasser, P. $\mathrm{IrO}_{x}$ core-shell nanocatalysts for cost- and energy-efficient electrochemical water splitting. Chem. Sci. 2014, 5, 2955-2963. [CrossRef]

298. Nong, H.N.; Oh, H.-S.; Reier, T.; Willinger, E.; Willinger, M.-G.; Petkov, V.; Teschner, D.; Strasser, P. Oxide-supported $\mathrm{IrNiO}_{x}$ core-shell particles as efficient, cost-effective, and stable catalysts for electrochemical water splitting. Angew. Chem. Int. Ed. 2015, 54, 2975-2979. [CrossRef] [PubMed]

299. Reier, T.; Pawolek, Z.; Cherevko, S.; Bruns, M.; Jones, T.; Teschner, D.; Selve, S.; Bergmann, A.; Nong, H.N.; Schlögl, R.; et al. Molecular insight in structure and activity of highly efficient, low-Ir Ir-Ni oxide catalysts for electrochemical water splitting (OER). J. Am. Chem. Soc. 2015, 137, 13031-13040. [CrossRef] [PubMed]

300. Ponce De León, C.; Walsh, F.C.; Bessette, R.R.; Patrissi, C.J.; Medeiros, M.G.; Rose, A.; Browning, D.; Lakeman, J.B.; Reeve, R.W. Recent developments in borohydride fuel cells. ECS Trans. 2008, 15, 25-49.

301. Demirci, U.B. Direct borohydride fuel cell: Main issues met by the membrane-electrodes-assembly and potential solutions. J. Power Sources 2007, 172, 676-687. [CrossRef]

302. Gyenge, E. Electrooxidation of borohydride on platinum and gold electrodes: Implications for direct borohydride fuel cells. Electrochim. Acta 2004, 49, 965-978. [CrossRef]

303. Chatenet, M.; Micoud, F.; Roche, I.; Chainet, E. Kinetics of sodium borohydride direct oxidation and oxygen reduction in sodium hydroxide electrolyte. Part $\mathrm{I}_{\text {. }} \mathrm{BH}_{4}{ }^{-}$electro-oxidation on $\mathrm{Au}$ and Ag catalysts. Electrochim. Acta 2006, 51, 5459-5467. [CrossRef]

304. Heng, H.; Scott, K. Determination of kinetic parameters for borohydride oxidation on a rotating Au disk electrode. Electrochim. Acta 2006, 51, 3429-3433.

305. Hosseini, M.G.; Abdolmaleki, M.; Nasirpouri, F. Investigation of the porous nanostructured Cu/Ni/AuNi electrode for sodium borohydride electrooxidation. Electrochim. Acta 2013, 114, 215-222. [CrossRef]

306. Song, C.; Zhang, D.; Wang, B.; Cai, Z.; Yan, P.; Sun, Y.; Ye, K.; Cao, D.; Cheng, K.; Wang, G. Uniformly grown PtCo-modified $\mathrm{Co}_{3} \mathrm{O}_{4}$ nanosheets as a highly efficient catalyst for sodium borohydride electrooxidation. Nano Res. 2016, 9, 3322-3333. [CrossRef]

307. Valiollahi, R.; Ojani, R. Pt hollow nanospheres/graphene electrocatalytic ability toward sodium borohydride oxidation: A study of morphology effect on electrocatalytic activity. J. Appl. Electrochem. 2017, 47, $205-212$. [CrossRef]

308. Brown, B.; Wolter, S.D.; Stoner, B.R.; Glass, J.T. Alloying effects of cosputtered gold-platinum thin films on the oxygen reduction reaction in acidic electrolyte. J. Electrochem. Soc. 2008, 155, B852-B859. [CrossRef]

309. Ruban, A.V.; Skriver, H.L.; Nørskov, J.K. Surface segregation energies in transition-metal alloys. Phys. Rev. $B$ 1999, 59, 15990-16000. [CrossRef]

310. Vanrenterghem, B.; Papaderakis, A.; Sotiropoulos, S.; Tsiplakides, D.; Balomenou, S.; Bals, S.; Breugelmans, T. The reduction of benzylbromide at Ag-Ni deposits prepared by galvanic replacement. Electrochim. Acta 2016, 196, 756-768. [CrossRef]

(C) 2017 by the authors. Licensee MDPI, Basel, Switzerland. This article is an open access article distributed under the terms and conditions of the Creative Commons Attribution (CC BY) license (http:/ / creativecommons.org/licenses/by/4.0/). 